(11) Nordic Council of Ministers

ENVIRONMENTAL IMPACTS AND POTENTIAL OF THE SHARING ECONOMY
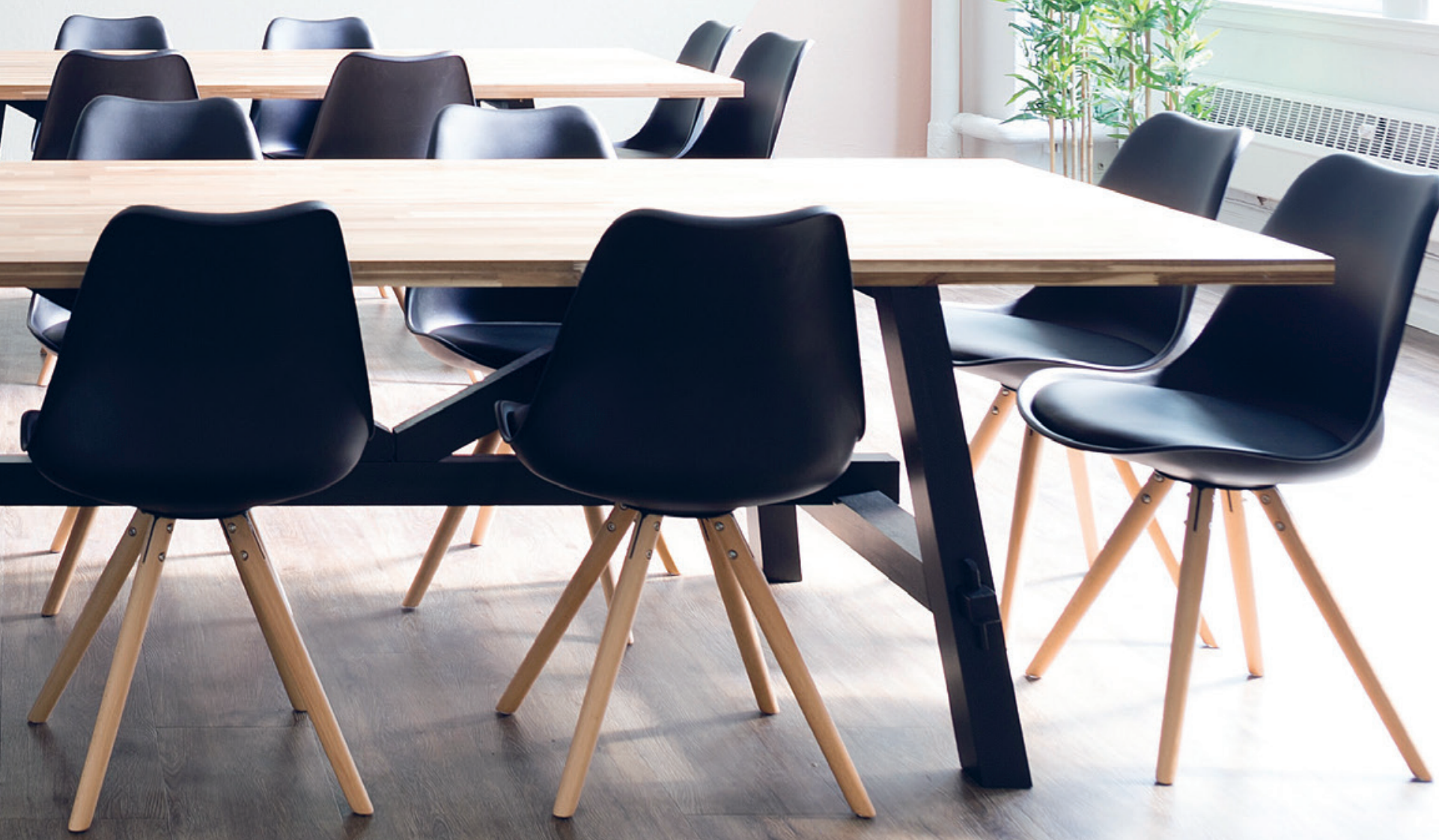



\section{Environmental impacts and potential of the sharing economy}

John Magne Skjelvik, Anne Maren Erlandsen and Oscar Haavardsholm

TemaNord 2017:554 


\section{Environmental impacts and potential of the sharing economy}

John Magne Skjelvik, Anne Maren Erlandsen and Oscar Haavardsholm

ISBN 978-92-893-5156-0 (PRINT)

ISBN 978-92-893-5157-7 (PDF)

ISBN 978-92-893-5158-4 (EPUB)

http://dx.doi.org/10.6027/TN2017-554

TemaNord 2017:554

ISSN 0908-6692

Standard: PDF/UA-1

ISO 14289-1

(c) Nordic Council of Ministers 2017

Cover photo: unsplash.com

Print: Rosendahls

Printed in Denmark

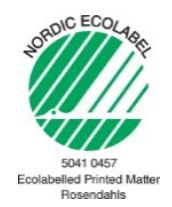

Although the Nordic Council of Ministers funded this publication, the contents do not necessarily reflect its views, policies or recommendations.

\section{Nordic co-operation}

Nordic co-operation is one of the world's most extensive forms of regional collaboration, involving Denmark, Finland, Iceland, Norway, Sweden, the Faroe Islands, Greenland, and Åland.

Nordic co-operation has firm traditions in politics, the economy, and culture. It plays an important role in European and international collaboration, and aims at creating a strong Nordic community in a strong Europe.

Nordic co-operation seeks to safeguard Nordic and regional interests and principles in the global community. Shared Nordic values help the region solidify its position as one of the world's most innovative and competitive. 


\section{Contents}

Preface

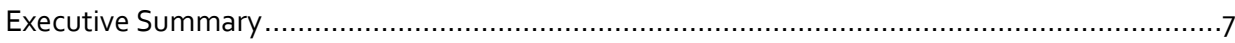

A digital platform, spare resources and persons are properties recognising the sharing

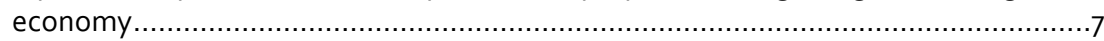

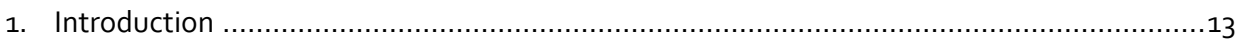

1.1 The sharing economy and the environment...............................................

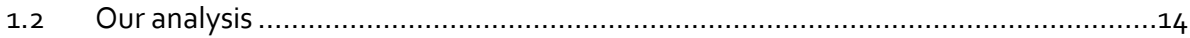

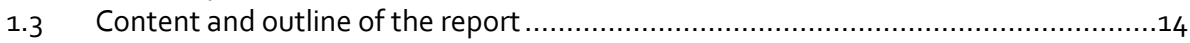

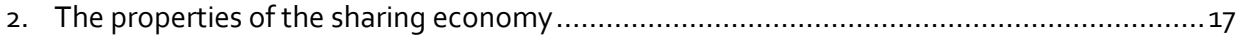

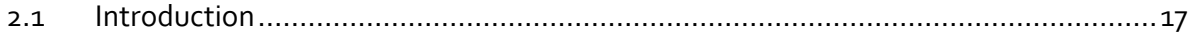

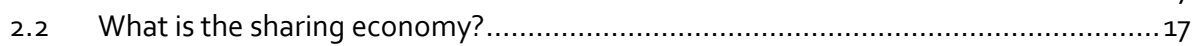

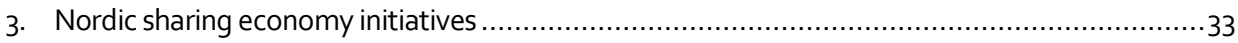

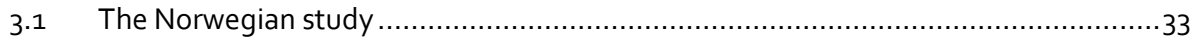

3.2 The sharing economy in the Nordic countries .............................................. 34

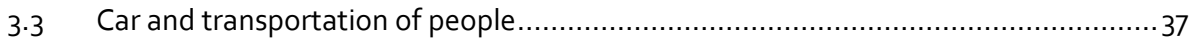

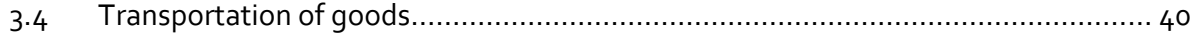

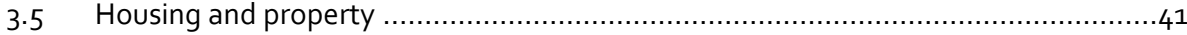

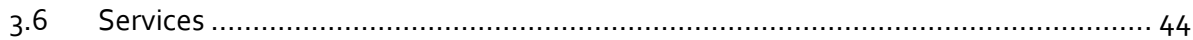

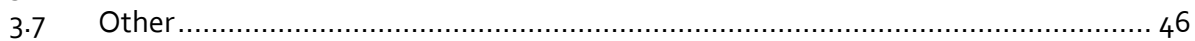

4. Some numerical illustrations of emission reduction potentials ....................................47

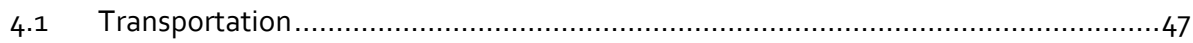

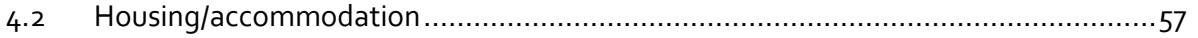

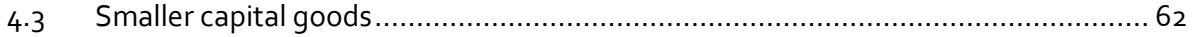

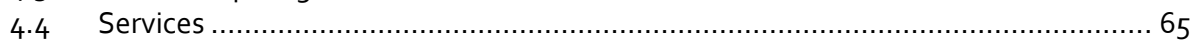

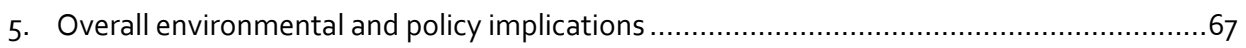

5.1 Several sharing initiatives have a potential to contribute to environmental

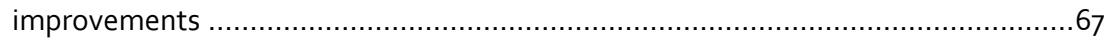

5.2 Sharing initiatives' impacts on overall emissions depend on the environmental policy

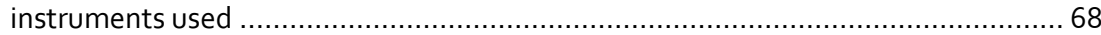

5.3 Sharing initiatives should be encouraged, and all emissions should be priced or

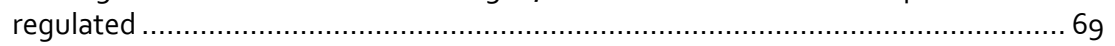

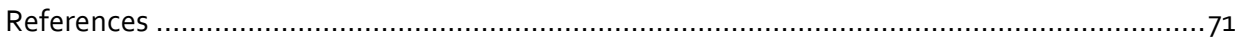

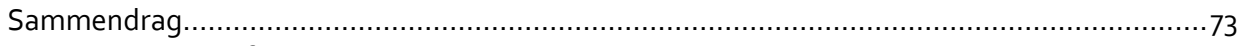

En digital plattform, underutnyttede ressurser og personer kjennetegner

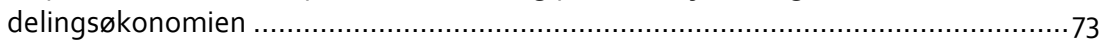





\section{Preface}

The concept of a "sharing economy" has recently emerged to give name to digital platforms for the exchange of services. It is often claimed that the sharing economy have, or might lead to, significant environmental benefits in the form of increased resource efficiency and reductions in environmental burdens. However, not much solid research has so far been done on this, theoretical or empirical.

This report gives an overview of some current sharing economy initiatives in the Nordic countries, analyses the change in consumer behavior that these initiatives could lead to, and assess what environmental impacts these changes might imply. It seems from the report that it is not evident that the sharing economy always lead to environmental improvements. Sometimes it is necessary to encourage sharing initiatives, and introduce supporting regulatory measures in order to achieve environmental benefits.

The report was funded by the Environment and Economy Group (MEG) and Sustainable Consumption and Production Group (HKP) under the Nordic Council of Ministers and prepared by Vista Analyse.

August 2017

\section{Signe Krarup}

Chairman of the Working Group on Environment and

Economy under the Nordic Council of Ministers 



\section{Executive Summary}

\section{A digital platform, spare resources and persons are properties recognising the sharing economy}

The concept of "sharing economy" is rather new, and there is no uniform definition as to what it comprises or how comprehensive the various sharing economy initiatives are. In our view the sharing economy initiatives could be defined as to fulfil the following three criteria:

- The transaction should cover a service based on goods or competence. Transactions of owner rights are not included.

- A digital platform (app) is a vital part of the service, as an intermediate between buyer and seller, and/or as part of the quality of the service.

- The initiative is established to carry out the service in the first bullet with the help of the technology of the second bullet.

These criteria are pragmatic, but seek to comprise what is the core of the sharing economy. Within it are the initiatives offering transactions between persons/consumers $\left(C_{2} C\right)$ and between businesses and persons ( $\left.B_{2} C\right)$, as well as business to business initiatives (B2B). The criteria cover the best known initiatives like Uber, Airbnb and similar. Several firms from the "old" economy are developing digital platforms to meet the competition from the sharing economy activities, for instance offering of various streaming services. We have not included them in our survey since we would like to focus on the new initiatives that offer different solutions than traditional firms.

\section{Our analysis covers four areas}

Our attempt has been to give an overview of some current sharing economy initiatives in the Nordic countries, analyze the change in consumer behavior that these initiatives could lead to, and to assess what environmental impacts these changes might imply. We have focused on the following four segments of the sharing economy:

- Transportation: various car sharing initiatives with or without driver, carpooling, transportation of goods and similar.

- Housing/accommodation: access to cheap accommodation in private homes. 
- Other, smaller capital goods: a large variety of machines and tools that consumers could borrow/rent instead of buying.

- Services: a large group covering various activities related to personal services.

\section{Transportation has the largest emissions reduction potential}

Our mapping of sharing economy initiatives in the Nordic countries shows that there are several initiatives that could lead to environmental improvements. Most initiatives are related to the transport sector, and this is the sector where the direct potential for emissions reductions is largest. There is a potential for $\mathrm{CO}_{2}$-equivalent $\left(\mathrm{CO}_{2} \mathrm{e}\right)$ emissions reductions from reduced driving of private cars and reduced car production, and reduced impacts on local air pollution, noise, traffic congestion etc. since most of these initiatives are located in cities where local environmental problems from transport are largest.

We have analyzed the potential for emissions reductions from sharing alternatives that offer services with lower prices and/or better qualities compared to owning and driving one's own car, but there are several other transport sharing initiatives that could yield similar reductions. Carpooling, where people ride together to and from work, could lead to emissions reductions if people previously drove their own car instead. Car hailing initiatives could yield similar benefits if people drive their own car less and/or don't own a car any more.

International studies show that households on average tend to reduce their vehicle holdings after becoming car-sharing members, indicating that one shared car could replace approximately 4 to 13 personal cars. Accounting for potential increases in newcar sales to car-sharing fleets and more heavy utilization of shared cars, $\mathrm{CO}_{2} \mathrm{e}$-emissions could be reduced by roughly 40 to $140 \mathrm{~kg}$ per member household per year from reduced production and maintenance etc. of cars. Households that substitute their personal car with a shared car generally drive less, because shared cars are relatively less accessible and the per-trip costs become more apparent compared to personal vehicles, although the total "car-costs" might be reduced. But some households that join car sharing drive more than before, since trips previously untraveled or traveled by other modes of transport, such as public transport, bicycling or walking, are substituted by trips in shared cars. The average net impact is a decrease in kilometers travelled, ranging between $90 \mathrm{~kg}$ and $840 \mathrm{~kg} \mathrm{CO} 2 \mathrm{e}$-emissions per households per year according to the studies we have reviewed.

Thus, the overall emissions reductions could be between some $130 \mathrm{~kg}$ to around $1,000 \mathrm{~kg} \mathrm{CO}$ e-emissions per household per year according to these estimates. These numbers are of course highly uncertain, and since the highest of the estimates are from the US they may not accurately represent Nordic conditions when it comes to driving distances and emissions per distance. Thus, Nordic emission reductions are likely somewhat closer to the lower part of the interval than to the higher part.

Reduced car transport could also reduce the demand for parking infrastructure. In addition, greater fuel efficiency because of newer cars and perhaps more use of electric and hybrid cars in car-sharing fleets compared to private cars could further reduce 
emissions. However, the use of public transport would likely increase because of reduced car ownership, that will in turn generate some emissions.

When people save money from reduced prices of some services, they will use all or some of these savings on other goods and services causing environmental harm. We have found that savings from participating in for instance a car sharing arrangement instead of owning one's own car could be considerable, and the use of these savings on other goods and services could partly, fully or more than offset initial environmental improvements. Examples from Denmark and Norway indicate that the indirect rebound effect could be as high as 3 tons and $814 \mathrm{~kg} \mathrm{CO} \mathrm{CO}_{2}$-emissions per car sharing member per year, using numbers for emissions from "average consumption." The size of the effect will depend on the amount of economic savings from car-sharing, how much of the savings car-sharers would spend, and the type of goods and services the money is spent on.

\section{Accomodation also has a potential for emissions reductions}

Private property accomodation through Airbnb and similar initiatives may lead to lower $\mathrm{CO}_{2} \mathrm{e}$-emissions because these properties may generate lower emissions than hotels. This is because hotels often have more energy intensive facilities like bars, restaurants, swimming pools and 24 -hour operation. It is also possible that Airbnb guests generate less water use and waste than hotel guests. However, Airbnb guests mostly compete with lower-end accommodation like hostels and motels, which generally have lower emissions and other environmental impacts than high-end hotels. Some higher-end Nordic hotel chains are working actively to reduce energy consumption and become more environmentally friendly, implying that the difference between the various accommodation alternatives might be coming down. A study commissioned by Airbnb estimates a reduced energy use of at least $88 \%$ by their users compared to hotel guests. By using this estimate on emissions from Nordic Choice and Scandic hotels there could be a reduction of $2-3 \mathrm{~kg} \mathrm{CO} 2 \mathrm{e}$-emissions per guest night from using Airbnb and similar initiatives compared to using Nordic hotels.

Private property accommodation could reduce the demand for new hotels in the longer term. This would lead to reduced $\mathrm{CO}_{2} \mathrm{e}$-emissions and local pollution from the construction process and the production of building materials, as well as less waste generation from leftover materials etc. However, the energy use from the operation of hotels accounts for some $85-90 \%$ of total life cycle emissions from hotels.

Cheaper rental prices could increase the demand for private accommodation, either in the form of longer stays or more trips. This depends on the sensitivity of consumers' demand to changes in price and income. The demand for air travel is typically highly sensitive to changes in income and price, implying that demand for air travel increases by more than the amount income is increased or prices reduced. This would indicate that a higher disposable income from lower accommodation prices is more likely to be spent on air travel than on other, less price- and income elastic goods and services. If a person because of cheaper accommodation decides to travel an extra return trip by airplane from Oslo to London, this could generate an emissions increase of around $800 \mathrm{~kg} \mathrm{CO}_{2} \mathrm{e}$. Private 
accommodation would have to substitute around 270-400 guest nights at hotels to offset these emissions, according to the numbers above.

\section{Renting of smaller capital goods could also lead to emissions reductions}

There are several Nordic sharing economy initiatives that match people who want to rent various small capital objects, such as tools, clothes etc. Privately owned tools are only used occasionally. For example, a power drill is only used around 18 minutes over its entire life span according to a study. The life cycle emissions from a power drill amount to around $28 \mathrm{~kg} \mathrm{CO}{ }_{2}$, and only $2 \%$ of the emissions are generated from the use of the drill.

An example from the Danish online service Lejdet, that facilitates the sharing of all kinds of items between people, shows that in 2014 power drills were shared 30 times. If 5 electric drills covered 30 rentals, i.e. each of the 5 drills were rented 6 times, the sharing suppressed the production of 25 electric drills, reducing emissions by $700 \mathrm{~kg}$ $\mathrm{CO}_{2} \mathrm{e}$. But sharing services may also induce increased traveling as people pick up the rented tools. If someone drives a return trip of 5 kilometers to pick up a hired drill instead of driving a similar distance to purchase the drill, there is no difference in emissions. Now imagine the person needs the power drill 9 more times over the years, and drives an average of $5 \mathrm{~km}$ each time, with emissions of $173 \mathrm{~g} / \mathrm{km}$, this would generate approximately $8 \mathrm{~kg} \mathrm{CO} 2$. In this instance, the additional emissions from induced driving would be lower than the $28 \mathrm{~kg}$ emissions saved from the production of a power drill.

But the alternative to using a shared tool may not always be to purchase a new one. In the absence of online sharing of tools, people might borrow or rent the tools from somewhere else in the neighborhood instead. More use of under-used tools because lending becomes cheaper could result in an increase in electricity use (for power tools) or fuels (e.g. lawn mowers) and associated environmental impacts.

Another example is from the clothes-sharing business Resecond, which facilitates sharing of dresses in Copenhagen and Århus. Customers can bring a dress they are no longer using, and in return pick another dress from the stock. If a dress that is assumed to be used six times and then thrown away instead is recycled 10, 15 or 25 times, one could save some 144,324 or $684 \mathrm{~kg} \mathrm{CO}$ e-emissions respectively from reduced purchase of new dresses. But if one purchases a dress second-hand instead of buying a new one, sharing would not result in any additional emission reductions. Also, if people travel more to pick up shared clothes compared to the travelling they would have done to buy new clothes, emissions reductions would be smaller and might even increase.

\section{Services seems to have less potential for emissions reductions}

There are some sharing economy companies that offer matching of services like transporting smaller goods, running errands, cleaning services, painting, gardening, maintenance etc. in the Nordic countries. Their environmental impacts largely depend on whether the services can be done remotely or whether the user must be present to 
perform the service. Services that in the sharing economy can be done remotely but earlier would have to be done on site could yield considerable environmental benefits.

The services that demand physical presence are typically smaller manual jobs, and the companies put the users in contact on their digital platform. Many of these are jobs that people previously had to do themselves or get help from others like neighbors or relatives to do.

The environmental impacts of these shared services depend on whether they induce increased driving. This will depend of what the alternative to the provision of the service would have been. If a person instead of paying someone to paint his house would have done it himself or perhaps not painted the house at all, the environmental impact would be the emissions generated from the transportation of the painter to and from the house. But if the house owner had painted it himself, he would perhaps have to go (drive) to and from a store to buy the paint. However, if the house owner would have paid a painting company to undertake the task, who also would have had to travel to and from the house, there would be no additional environmental impacts from the shared service. And if the house owner saves money from using the new services he will spend (some of) these on goods and services that in turn cause environmental impacts.

\section{Sharing initiatives' environmental impacts depend on the environmental policy instruments used}

In the Nordic countries $\mathrm{CO}_{2}$ emissions from transportation and some other sectors are taxed through fuel taxes, and in some countries also through purchase taxes on vehicles. Furthermore, $\mathrm{CO}_{2}$ emissions from aviation, electricity, car and building material production and most other production activities are covered by the EU emissions trading scheme ETS, which also comprises Iceland and Norway. Thus, if for instance emissions from aviation increase, emissions from other sectors covered by the trading scheme will be reduced to keep overall emissions within the total cap, assuming that the cap is effective, which it hasn't always been.

When countries have introduced cost efficient climate change policies, where all $\mathrm{CO}_{2}$ and other GHG emissions have the same price either through a tax or emissions trading system, people are faced with a price on emissions, so that this is taken into account when they make their choices on what to spend their money on.

But not all $\mathrm{CO}_{2} \mathrm{e}$ emissions are covered by taxes or EU ETS. Most of the policy measures cover only $\mathrm{CO}_{2}$, and not other GHGs. Goods imported from outside the EEA are often not covered by any emissions regulations, for instance does the EU ETS only cover intra-EEA flights. But this could change in the future, since countries outside the EEA area could eventually take actions against $\mathrm{CO}_{2}$ emissions.

Road transport is an important contributor to problems related to local air pollution, noise, road congestion and accidents, and these problems mostly occur in (larger) cities. As far as the sharing initiatives lead to less driving in cities they would have positive impacts on these problems. Carpooling and sharing might make congestion regulations etc. more efficient by offering alternatives to driving alone in private cars. Even if the traffic isn't reduced substantially, car sharing initiatives might 
contribute to improved air quality by speeding up the introduction of low and zero emission cars.

In the long run impacts from the sharing economy initiatives might be somewhat different from today. If we all in some years drive in zero emission, (self-driven) cars, car transport will no longer contribute to $\mathrm{CO}_{2} \mathrm{e}$ emissions and reduced local air quality. The sharing initiatives could become an element in an integrated, intermodal transport system. One can imagine that in the future personal cars are no longer common, at least in cities, and that fleets of autonomous electric vehicles provide transportation with higher levels of service, faster rides and increased safety at a far lower price than today's individually owned cars. These fleets could include a wide variety of vehicle types, sizes and configurations that meet every kind of consumer needs. But in cities there could still be problems related to congestion and eventually noise, which would have to be dealt with.

Sharing initiatives should be facilitated, and all emissions should be priced or regulated

Sharing economy initiatives could yield considerable benefits to consumers, and might also improve the overall efficiency of the economy, leading to better/more use of existing cars, dwellings and other goods, and reduced production of new units. Authorities should take the opportunity to go through various regulations to see if there are some (un-necessary) ones that are hampering the introduction of sharing initiatives, and eventually could be removed.

More efficient use of the resources through sharing initiatives could also contribute to environmental benefits, but this depends on how people change their behavior and spend their savings from using the initiatives. But if all GHG emissions faces a high price, and local environmental challenges are regulated properly, sharing initiatives should contribute to higher consumer benefits and a more efficient economy at least without harming the environment. 


\section{Introduction}

In this Chapter we present the background for the study.

\subsection{The sharing economy and the environment}

The concept of "sharing economy" has become a buzzword for (new) digital connections between single persons and/or legal persons facilitating exchange of services and/or sharing of goods, property, resources, competence or capital through digital platforms. There is no distinct definition of the "sharing economy concept", but there are some broad characteristic features that are often used to recognize the sharing economy when one sees it. The essence in the definition seems to be that through using (new) digital platforms one is able to create new market opportunities and business models for more effective utilization of goods like dwellings, cars, tools, and easier provide services like personal care, garden care, house repair etc. by reducing transaction costs and making the goods and services more available through larger networks. This could ultimately lead to less private ownership of goods, if people can instead rent or borrow goods from others.

The various initiatives could be separated into the following categories:

- Consumer to consumer $\left(\mathrm{C}_{2} \mathrm{C}\right)$, also called Peer to peer $\left(\mathrm{P}_{2} \mathrm{P}\right)$ : connections between persons/households.

- Business to consumers $\left(\mathrm{B}_{2} \mathrm{C}\right)$ : Connections between companies and persons.

- Business to business (B2B): Connections between companies.

Most of the focus of the sharing economy has so far been on the first two types of connections. Airbnb is an example of offering $\mathrm{C}_{2} \mathrm{C}$ connections to share accommodation, while Hotels.com and Bookings.com are examples of $\mathrm{B}_{2} \mathrm{C}$ connections of accommodation. B2B has so far perhaps had little focus, but offer great potential.

In public debate there seems to be a perception that the concept of sharing economy is positive for the environment, contributing to reduced emissions and reduced use of scarce resources etc. As an example, car sharing initiatives give families car access without owning their own car. This could reduce global car production and thus save $\mathrm{CO}_{2}$ and other emissions. While this may show the "first order" impacts of some initiatives, one has to take into account the so-called "rebound effects", or price and income effects from the sharing economy. If the price of a good or service is reduced because of sharing economy initiatives, people tend to want more of it. In our example, some families will have cheaper and easier access to cars and thus drive more than they would otherwise 
do, thus increasing emissions. This is the price effect (rebound through price). Besides, some of the expenses saved from the lowered price will likely be used to buy other goods and services, this is the income effect (rebound through income or indirect rebound effect). Families saving money from not having their own car might use (some of) the money saved for instance to fly on vacation abroad, contributing to increased $\mathrm{CO}_{2}$ emissions. This increased consumption will imply increased environmental burdens, which might partly or fully offset the initial emission reductions.

Similarly, access to cheaper accommodation in private homes could imply that people travel more, leading to increased emissions. However, in the longer run these initiatives could lead to reduced need for new hotels, thus contributing to offset wholly or partly the initial emission increases.

These examples show that the total environmental impacts from the various sharing economy initiatives are hard to predict and calculate. However, some studies have analyzed this, and our attempt through this proposal is to provide an overview of the results that are most relevant in a Nordic perspective with some examples of what the total environmental impacts might be for some of the main $\mathrm{C}_{2} \mathrm{C}$ and $\mathrm{B}_{2} \mathrm{C}$ initiatives.

\subsection{Our analysis}

Our attempt has been to give an overview of some current sharing economy initiatives in the Nordic countries, analyze the change in consumer behavior that these initiatives could lead to, and assess what environmental impacts these changes might imply. We have focused on the following four segments of the sharing economy:

- Transportation: Various car sharing initiatives with or without driver, carpooling, transportation of goods and similar.

- Housing/accommodation: Access to cheap accommodation in private homes.

- Other, smaller capital goods: This could comprise a large variety of machines and tools that consumers could borrow/rent instead of buying.

- Services: This is a large group covering various activities related to personal services at site or online.

\subsection{Content and outline of the report}

In chapter 2 we give an overview of the properties of the sharing economy in the Nordic countries, starting by defining the sharing economy and the division into the four main segments described above. Chapter 3 presents some current sharing economy initiatives in the Nordic countries. In chapter 4 we go through various studies analyzing potential environmental impacts of these sharing economy initiatives, focusing on numerical examples covering the main segments. Chapter 5 summarizes the main findings, and discusses what political impacts (if any) these should lead to. 
Our main attention has been on greenhouse gas ( $\mathrm{GHG}$ ) emissions noted as $\mathrm{CO}_{2} \mathrm{e}$ (carbon dioxide equivalent) emissions, since these are the environmental problem most focused on globally. Besides, the availability of data makes it relatively easy to analyze impacts on $\mathrm{CO}_{2}$ emissions through the whole value chain from production to use and waste treatment compared to other environmental problems. However, we have to the extent possible also tried to look at the impacts on other pollutants, such as impacts on local air quality (PM, NOx), noise etc. to get a broader picture of the environmental impacts. But lack of data has made it difficult to give a good, overall picture of these impacts. 



\section{The properties of the sharing economy}

\subsection{Introduction}

In this chapter we define the sharing economy and how we divide it into four main segments in this report. Then we go through the main advantages with the sharing economy compared to more traditional ways of production and consumption.

The definitions and to some extent the overview is partly based a study of the sharing economy in Norway that was done by Vista Analyse for the Norwegian Ministry of Local Government and Modernization in 2016, see Vista Analyse (2016).

\subsection{What is the sharing economy?}

How one defines the sharing economy will be important to the results of our analysis. There is a gliding scale of initiatives that can be counted as part of the sharing economy depending on what boundaries one sets for the definition, but there is a core of initiatives which most people think of as part of the sharing economy. We find it useful to group the sharing initiatives according to how close to the center of the definition they fall.

\subsubsection{Different definitions in the literature}

The Wikipedia page on the sharing economy gives a good introduction to the term:

Sharing economy is an umbrella term with a range of meanings, often used to describe economic and social activity involving online transactions. Originally growing out of the open-source community to refer to peer-to-peer based sharing of access to goods and services, the term is now sometimes used in a broader sense to describe any sales transactions that are done via online market places, even ones that are business to consumer, rather than peer-to-peer. For this reason, the term sharing economy has been criticized as misleading, some arguing that even services that enable peer-to-peer exchange can be primarily profit-driven. However, many commentators assert that the term is still valid as a means of describing a generally more democratized marketplace, even when it's applied to a broader spectrum of services. 
The sharing economy has no precise and universally accepted definition. Even though people use it differently and there is strong disagreement about the use of it as a term, it has become widespread. The sharing economy relates to many things, and the ambiguity of the label reflects the ambiguity of the subject matter. As one tries to define its meaning, one finds that there are many things related to the subject that needs to be described and understood.

In the invitation to the open tender for this project on the environmental impact and potential of the "sharing economy" from The Nordic Council of Ministers, the sharing economy is described as follows:

\footnotetext{
The concept of a "sharing economy" has recently emerged to give name to digital platforms (smartphone applications with associated websites and databases) for exchange of services. The most prominent examples are private dwellings used as hotel rooms (Airbnb) and transport services by private cars (Uber). This is different from ordinary e-commerce with goods, and usually $\mathrm{C}_{2} \mathrm{C}$-based (Consumer-to-Consumer) while most e-commerce is $\mathrm{B}_{2} \mathrm{C}$-based (Business-toConsumer), but this division is not at all clear-cut. Some of these business models have expanded rapidly after the introduction of smartphones, e.g. Apple's iPhone and a large range of Androidbased models, since 2007. The term "sharing economy" is often used to include examples both commercial and those based on genuine sharing; the first category could more appropriately be called "exchange economy". Genuinely free, cooperative sharing has solid digital traditions (e.g. Linux, the Gutenberg project, Wikipedia), and several examples of true "sharing economy" networks (or "collaborative consumption", in EU parlance) exist. The best-known examples (above) are however, new business models, where the "new" element is a digital platform based on smartphone applications. "Sharing economy" ("delingsøkonomi") is thus a misnomer for this broader category of "sharing" networks and profit-based business models. Car sharing schemes as well as digital platforms for Consumer-to-Consumer exchange of second-hand products (such as eBay, or Finn.no in Norway) also belong in this larger, broader category, for which this, somewhat misleading, term has now become established usage".
}

The Nordic Council of Ministers, 2016

The Nordic Council of Ministers points out that the sharing economy has become a name for a broad category of "sharing" networks and profit-based business models. They use a quite broad definition, claiming that the sharing economy is digital platforms for exchange of services. This addresses two important characteristics. That the activity happens across digital platforms, and that there is an exchange of services (not goods). However, many services are bought and sold over digital platforms, and most of them are not part of what most people associate with the sharing economy. Flight tickets, hotel rooms, public transportation tickets, taxi rides etc. can be bought on/through digital platforms. In fact, most industries today have some online presence and the possibility of buying their products or services on those platforms.

There is no definition which is precise enough to include all the aspects one wishes to include and at the same time encompasses only the initiatives people usually think of as part of the sharing economy. There is a spectrum of initiatives that can be part of the sharing economy depending on the limits you draw, but there is a core of initiatives that most people recognize as part of the sharing economy, for example Airbnb, Uber etc. These businesses have certain characteristics: they are critically dependent on a 
digital platform, the platform ensures matching of people and lowering of transaction costs, and leads to better resource utilization. The services are often peer-to-peer, meaning that they are decentralized and people can be producers as well as consumers of the services. There are rating systems that ensure trust and quality.

The new business model of these companies is based on a third-party model, see Figure 1 The sharing economy initiative is just a "middle man". They simply put people in touch with each other through their digital platform. The platform lowers the transaction costs and makes transactions, that earlier were not being made, possible and profitable. The sharing economy initiatives do not own the capital or offer the services, they simply tap into the large pool of unused or underutilized goods, time and knowledge.

Figure 1: The third-party business model of sharing economy companies

\section{Platform}

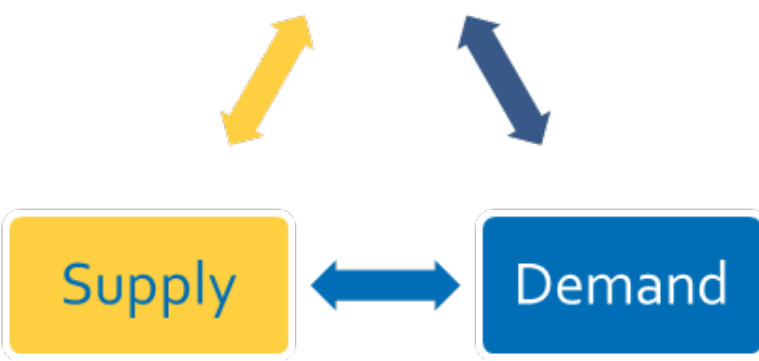

Source: Vista Analyse.

The sharing economy allows for people to rent instead of owning things, such as cars, or to get help with tasks, while creating an opportunity for other people to make money from their idle possessions or talents.

When trying to define the sharing economy one soon finds that there is a problem with limiting what should fall within the definition. The Wikipedia page on The Sharing Economy says that there are a number of attempts at defining the sharing economy, from the narrow to the wide:

A variety of definitions exist. "The people who share" is one of the broadest definitions, which encompasses the on-demand economy, the gig economy, social media, and a great deal else. Academic definitions tend to be narrower, limiting the sharing economy to only peer-to-peer transactions, and sometimes further limiting the definition to only peer to peer transactions that relate to the temporary exchange of physical goods. ${ }^{1}$ Another set of narrow definitions used by free culture activists, members of the co-operative movement and similar, excludes for-profit companies from the sharing economy, even if they facilitate just peer to peer transactions. Sometimes called the "real" or "true" sharing economy, organisations that operate within such definitions are mostly small and localist, run by volunteers on a cooperative basis, though

${ }^{1}$ Here Wikipedia references a report by Goudin (2016). 
sometimes also by governments and municipal authorities. They can include some organisations that operate without online transactions, such as bike kitchens. The "true" sharing economy does include some large internationally available web sites however, such as Freecycle.

"Sharing Economy", 2017

"The people who share" is according to Wikipedia the wide definition, while the transactions between private individuals and the renting of physical objects/capital are elements in a narrower definition. An even narrower definition excludes transactions by a for-profit agent.

Organizations, movements, websites and bloggers are interested in the sharing economy and have suggested definitions. Ouishare presents them-/itself as "The think and be-tank for a collaborative society", and defines the collaborative economy as follows: ${ }^{2}$

\begin{abstract}
The collaborative economy is defined as initiatives based on horizontal networks and participation of a community. It is built on "distributed power and trust within communities as opposed to centralized institutions" (R. Botsman), blurring the lines between producer and consumer. These communities meet and interact on online networks and peer-to-peer platforms, as well as in shared spaces such as fablabs and coworking spaces.
\end{abstract}

This definition puts emphasis on digital platforms and other spaces where people switch between being a producer and a consumer.

Another organization or movement is The People Who Share, whose goal is "to mainstream the sharing economy worldwide." Their definition is quite wide: ${ }^{3}$

\footnotetext{
The Sharing Economy is a socio-economic ecosystem built around the sharing of human, physical and intellectual resources. (...)

A Sharing Economy enables different forms of value exchange and is a hybrid economy. It encompasses the following aspects: swapping, exchanging, collective purchasing, collaborative consumption, shared ownership, shared value, co-operatives, co-creation, recycling, upcycling, redistribution, trading used goods, renting, borrowing, lending, subscription based models, peer-topeer, collaborative economy, circular economy, on-demand economy, gig economy, crowd economy, pay-as-you-use economy, wikinomics, peer-to-peer lending, micro financing, micro-entrepreneurship, social media, the Mesh, social enterprise, futurology, crowdfunding, crowdsourcing, cradle-to-cradle, open source, open data, user generated content (UGC) and public services.
}

We presume that the ecosystem signalizes a system where the agents, primarily private individuals, are dependent on each other and change between being producers and consumers.

\footnotetext{
${ }^{2}$ http://ouishare.net/en/about/collaborative_economy

3 The definition is written by Benita Matofska, Chief Sharer in The People Who Share.
} 
There has also been written several books on the topic. (Gansky, 2010) touches upon many of the central aspects of later definitions when she writes:

- The core offering is something that can be shared, within a community, market, or value chain, including products, services, and raw materials.

- Advanced Web and mobile data networks are used to track goods and aggregate usage, customer, and product information.

- The focus is on shareable physical goods, including the materials used, which makes local delivery of services and products - and their recovery - valuable and relevant.

- Offers, news, and recommendations are transmitted largely through word of mouth, augmented by social network services.

In his book, (Stephany, 2015) puts it simply:

The sharing economy is the value in taking underutilized assets and making them accessible online to a community, leading to a reduced need for ownership of those assets.

In his book, (Sundararajan, 2016) identifies five points in his definition of the sharing economy:

1. Largely market-based: the sharing economy creates markets that enable the exchange of goods and the emergence of new services, resulting in potentially higher levels of economic activity.

2. High-impact capital: the sharing economy opens new opportunities for everything, from assets and skills to time and money, to be used at levels closer to their full capacity.

3. Crowd-based "networks" rather than centralized institutions or "hierarchies": the supply of capital and labor comes from decentralized crowds of individuals rather than corporate or state aggregates; future exchange may be mediated by distributed crowd-based marketplaces rather than by centralized third parties.

4. Blurring lines between the personal and the professional: the supply of labor and services often commercializes and scales peer-to-peer activities like giving someone a ride or lending someone money, activities which used to be considered "personal."

5. Blurring lines between fully employed and casual labor, between independent and dependent employment, between work and leisure: many traditionally full-time jobs are supplanted by contract work that features a continuum of levels of time commitment, granularity, economic dependence, and entrepreneurship. 


\subsubsection{From the core of the definition to its fringes}

Our summary of the definitions above is that they all gravitate around Gansky's three first points - the kind of object and services that are shared, characteristics of those that share them and the use of digital platforms as means of facilitating the sharing.

A possible way of thinking about this in a practical manner is by dividing the activities in the sharing economy in categories or circles, see Figure 2.

Figure 2: Different circles of The Sharing Economy

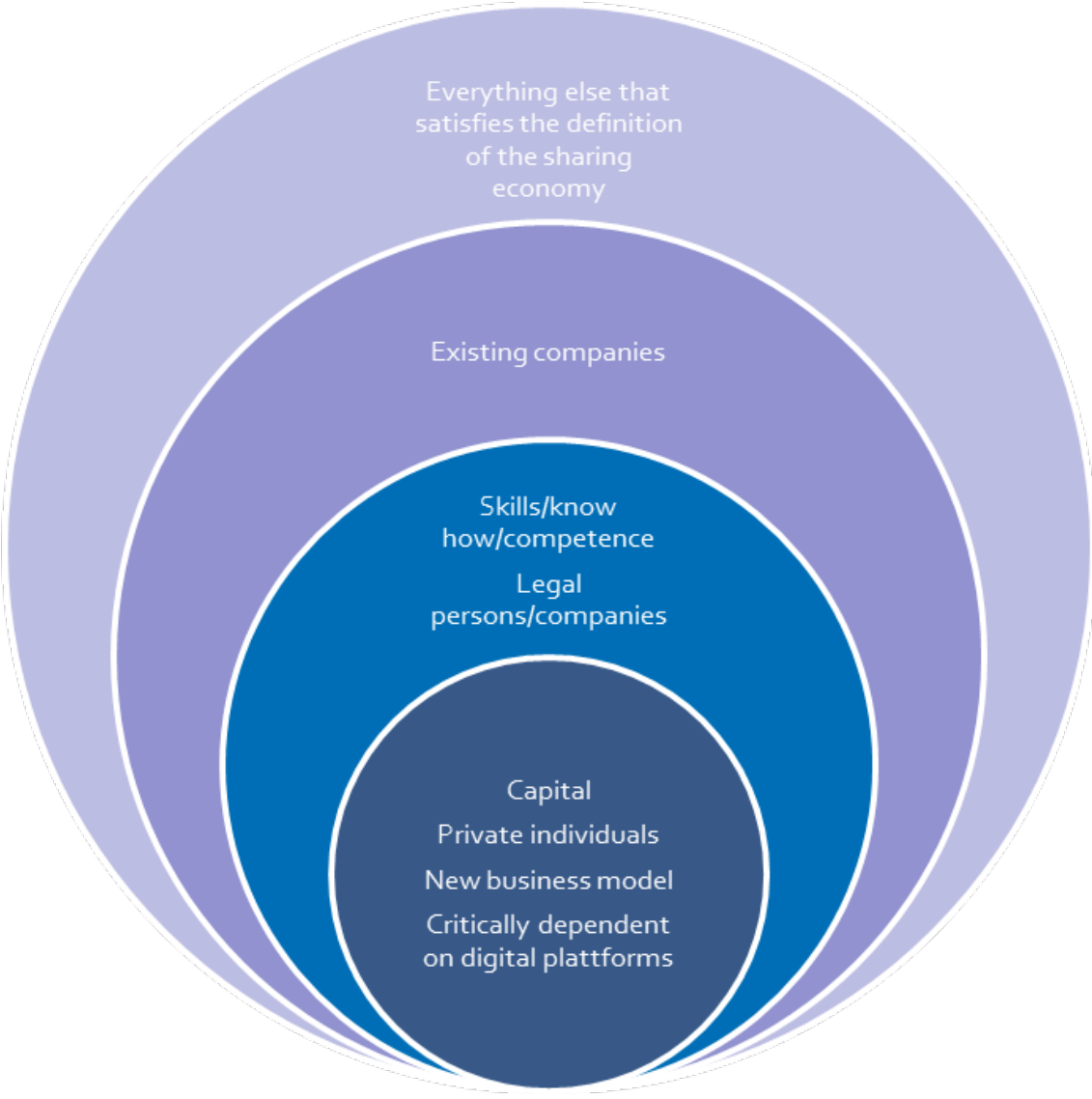

Source: Vista Analyse (2016).

In the inner circle, we find initiatives that most people agree are in the sharing economy. They are characterized by their new business model which is critically dependent on digital platforms and that facilitate sharing or renting of capital between private individuals. The initiative, however, can be a company (Airbnb, Uber etc.). We recognize these companies as part of the sharing economy when we see them.

In the second most inner circle we place facilitation of services other than capital, especially labor and/or skills. An example is WeClean, who facilitates cleaning services. For many more examples, see Chapter 3. In this circle, we also include legal persons/companies on the supply or demand side. 
In the third circle from the center we place older companies that utilize new technology and digital platforms. Here there are a lot of examples. Finn.no, the established taxi companies, car rental companies etc. Activities where the public sector is central on the supply side is also part of this circle. This includes for example bike sharing in some cities.

In the fourth circle from the center we have companies that meet the formal definitions of sharing economy in the chapter above, but are not part of our understanding of the sharing economy. This could be because they are largely dominated by companies, they are old/have traditional business models and not critically dependent on the digital platform. Examples of this can be public transportation, hotels.com and online courses (including massive open online courses, MOOCs).

\subsubsection{We focus on the two inner circles}

In our study of the sharing economy initiatives in the Nordic countries we focus on the two inner circles and their environmental effects. This entails that we study initiatives that:

- enable the exchange of services from capital or human capital

- enable the exchange of services between private individuals and/or companies

- are critically dependent on a digital platform.

A practical reason for including companies is that initiatives that formally facilitated services between private individuals, over time have got a larger part of companies on both the supply and demand side. For example, more and more companies are accepting stays at Airbnb and transportation with Uber as travel expenses.

The limit of our focus on the two inner circles excludes initiatives that are not obvious. Amongst other things we exclude sharing initiatives run by established old companies. The rationale behind this is not strictly principal, but rather that old companies are not perceived by many as part of the sharing economy.

We choose not to focus on financial services including peer-to-peer lending and crowdfunding. We also exclude streaming of music, videos and digital books and magazines. These are information goods that are of a different character than other goods and services. This includes libraries which also are public providers on the supply side.

\subsubsection{Categorizing of the sharing economy initiatives}

We find it useful to divide the services from capital in the main categories housing and property on one side and car and transport on the other. In addition, we have services and a residual category for all the other initiatives. Furthermore, we have created 
subcategories in each of the main categories. See Figure 3 for an overview of the sharing economy categories.

Figure 3: The sharing economy categories

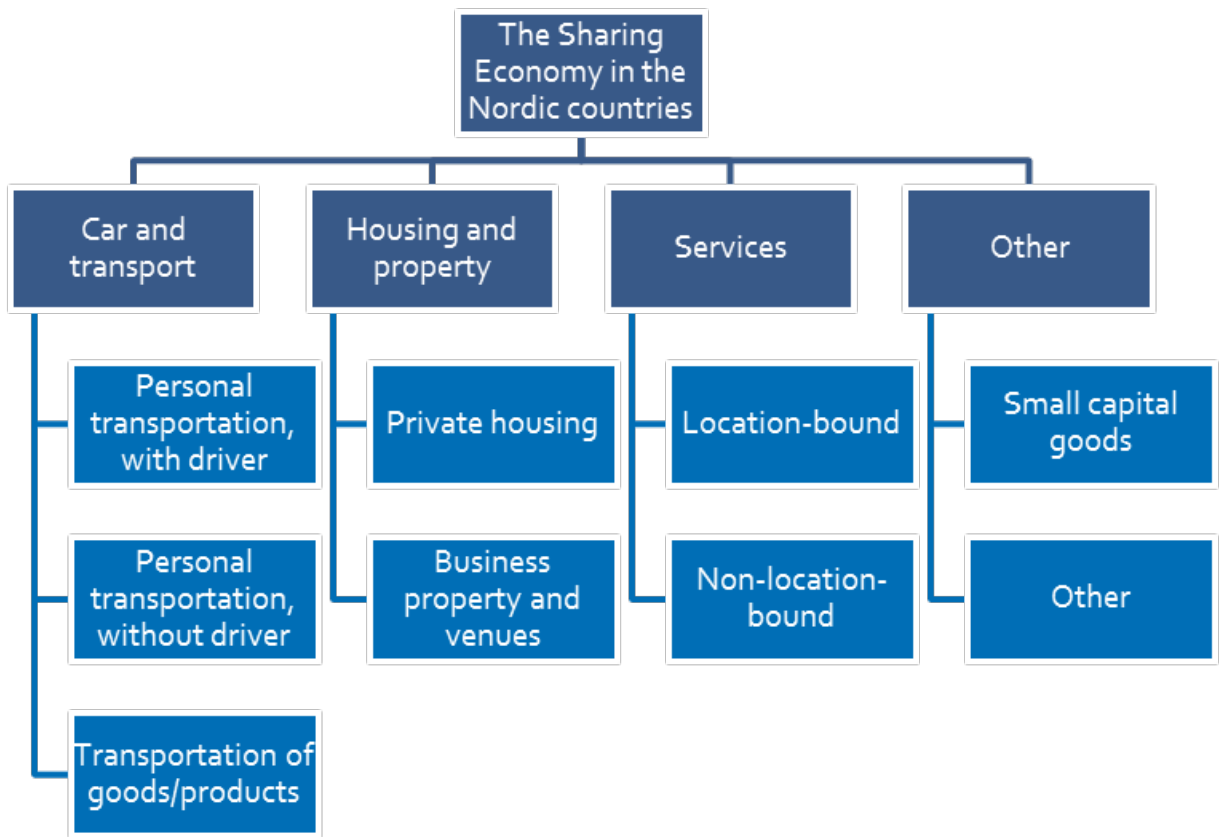

Source: Vista Analyse (2016).

\subsubsection{Advantages of the sharing activities}

In this subchapter, we present the advantages of the sharing economy in the market. It is useful to understand theoretical mechanisms that drive the sharing economy's success. We will also briefly discuss some of the challenges and potential downsides of the sharing economy.

\subsubsection{Advantages of the sharing economy activities}

- Price: the sharing economy services are offered at a lower price, which make them interesting for the customers.

- Cost: the low price has its origin in the fact that the services are cost efficient. They use information to match supply and demand in ways that lead to better resource utilization. This involves a cost saving compared to having to offer the services themselves.

- Quality: the sharing economy services are, to many customers, better than traditional alternatives. The services are based on applications (digital platforms) that have attractive functionalities, such as rating, overview of offers, customization, simple payment solution etc. 
- Culture: for some costumers, the sharing economy's cultural connotations are important. They like that the sharing economy can lead to lower environmental impacts, that they challenge the traditional companies that may have too much power and/or bad service, that they erase the division between producer and consumer and that they induce a feeling of community.

- Transaction costs: the application does not only have functions to improve the quality of the service. Probably the most important function, as with payment options and smart telephones etc., is making more transactions feasible. People with underutilized resources can, through the app, connect with costumers with a need for that exact thing. This makes it possible to deliver efficient services to a low price and of high quality/culture (in other words the four first bullet points).

- Contagion: because the sharing economy challenges the traditional economy, technological and cost-efficient solutions may be adopted by the traditional companies.

We can capture all the advantages of the sharing economy activities in quality and cost, based on technology.

It is useful to isolate the effects of lower cost and higher quality before we study the combined effect. We first study the effect of lower costs and assume that the quality of services is the same for all providers, see Figure 4 . We assume that the sharing economy service is qualitatively equal to that of a traditional provider, but that sharing economy service has a lower cost of provision. The cost of the sharing economy service includes both the cost of the provider of the service and the platform, i.e. Airbnb etc. The opportunity cost of labor is also included. Since all the services are of the same quality, there is only on e price in this market.

Figure 4: The effect of lower cost of the service provided

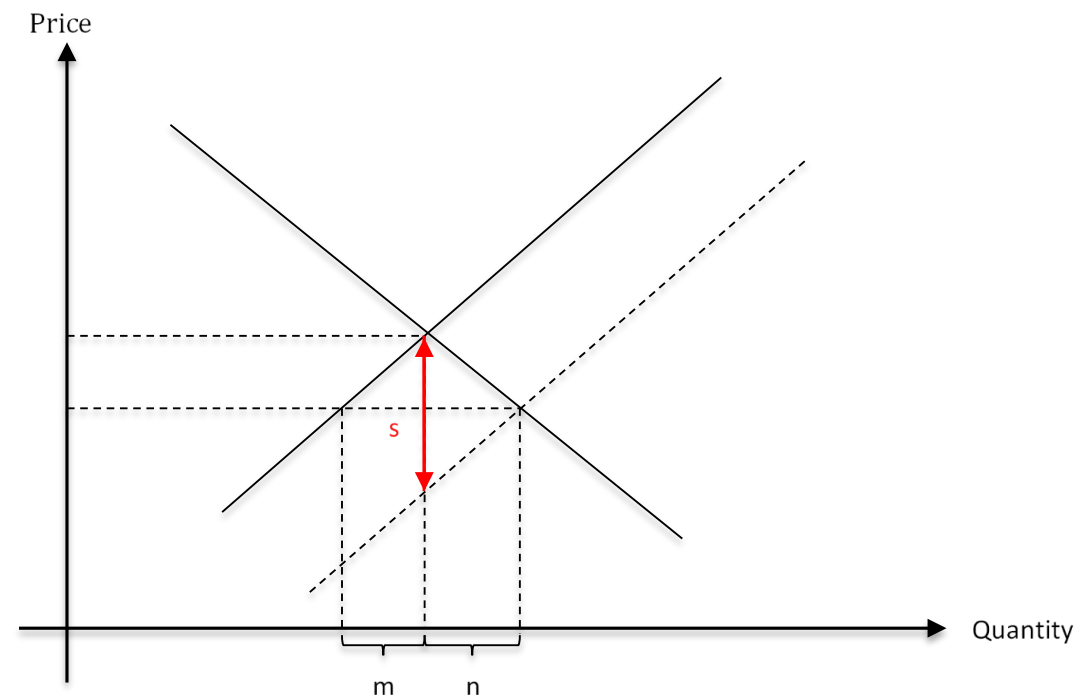

Source: Vista Analyse (2016). 
In a theoretical model of this market, a new provider that can offer the service to a lower price, creates a downward shift in the supply curve. The shift leads to a lower price and a larger quantity of transactions. The new provider will take some market share from the incumbents $(m)$ and partly generate new activity in the market $(n)$. How much of their business is taken from others and how much is generated by new transactions depend on the slope of the curves.

An important prediction from this model is that the price will go down in this market. There is evidence of this happening in the markets where sharing economy initiatives have had considerable success. This has for example been the case in many cities after Uber and other taxi-like services have been introduced: the new service has lowered the price, and incumbents have lost customers to the new ride hailing apps. At the same time the market has increased, but the market share of the new initiatives has increased more.

The model predicts the relationship between price reduction, increase in volume and cost saving. The cost saving comes from the fact that the new services can utilize underutilized capital and human capital. The gain in productivity is represented by the downward shift in the supply curve, equal to the distance in Figure 3. The market price is not reduced by the same amount, meaning that the gain in productivity is shared between the consumers (who get a lower price) and the producers who can convert some of the gain in productivity into profits.

We now turn to the other case, where the price is equal but the quality of the sharing economy service is higher, see Figure 5 . In this case, there is a positive shift in the demand curve, since the consumers are willing to pay more for the service because of its higher quality. In this case, the price increases as well as the quantity of services sold. The sharing economy increases the market ( $n$ ) as well as takes part of the incumbents' business $(m)$. The rise in willingness to pay is shared between the consum

Figure 5: The effect of higher quality in the service provided

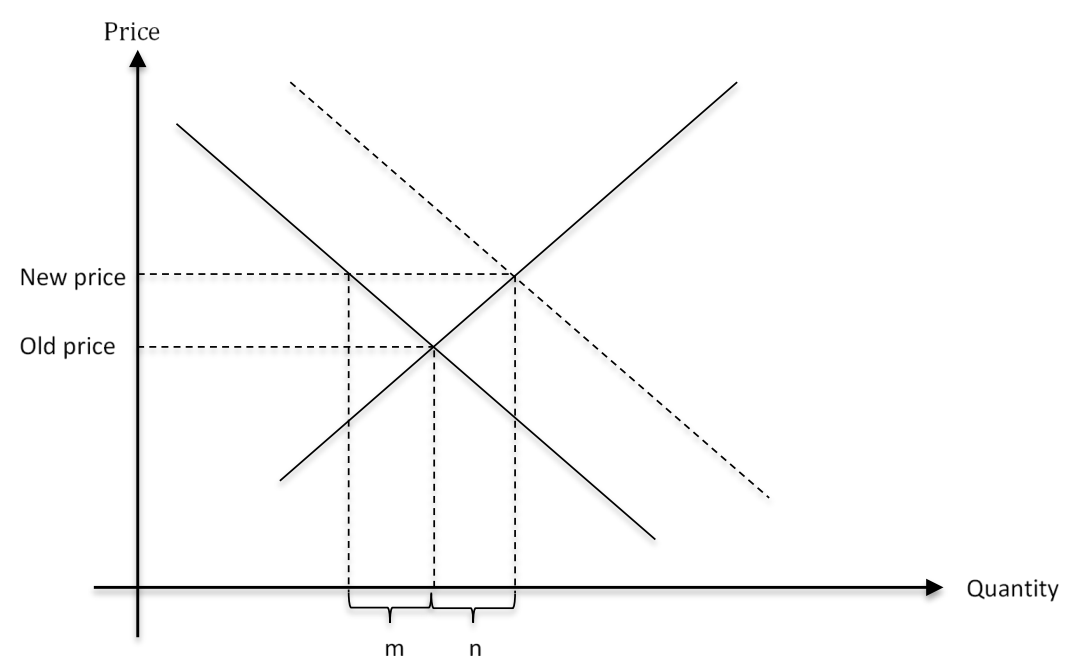

Source: Vista Analyse (2016).

ers (as increased benefit) and producers (increased profits). 
The combined effect of lower costs and increased quality is illustrated in Figure 6.

Figure 6: The effect of both lower cost and higher quality

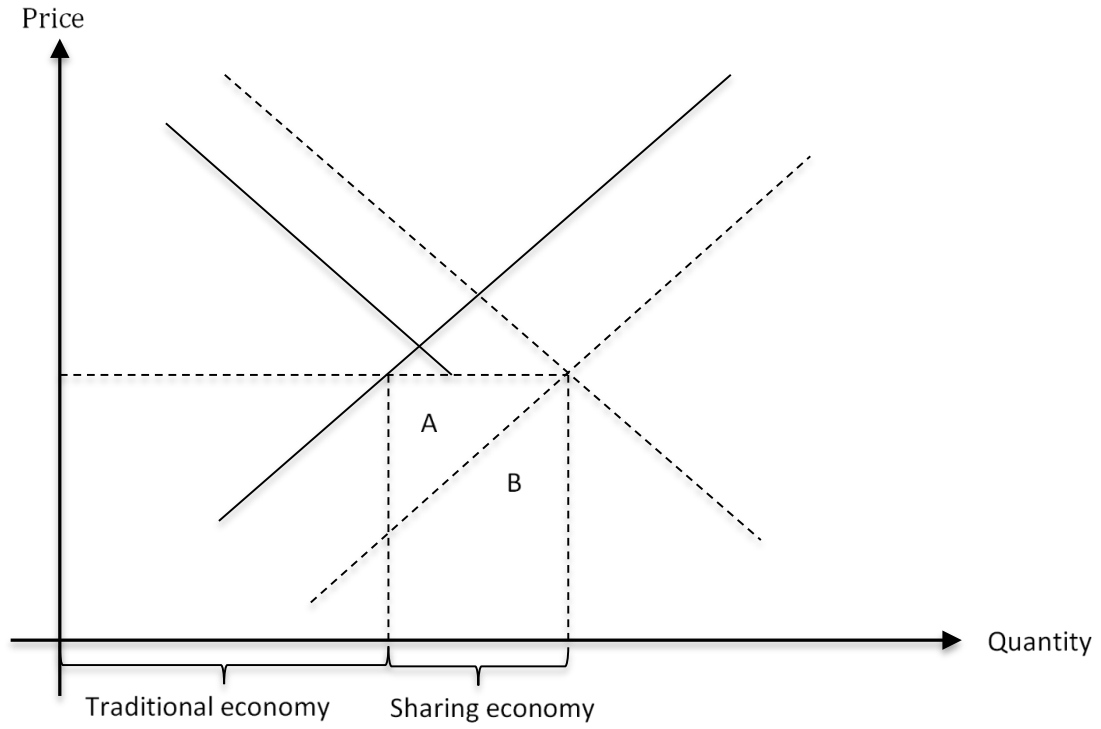

Source: Vista Analyse (2016).

The effect on the price in the market (down in the case of lower cost, up in the case of higher quality) tends to offset each other so that the price does not change dramatically. The effect on the quantity in both cases leads to a higher quantity of services sold. In the theoretical example in Figure 6 , the price goes down a little and the quantity increases a lot. This entails that some of the incumbents are forced out of the market since they cannot compete with the new competitors. But the majority of the service providers exist side by side with the sharing economy in this market, which has now grown considerably.

The revenue of the sharing economy is equal to the area $A+B$ in the figure. The wealth creation is equal to the area $A$, which is the revenue minus the costs, $B$. The effect of lower cost and higher quality on price and quantity depends on the slope of the supply and demand curves.

\subsubsection{The impact of the sharing economy on the Nordic economies}

It is not clear whether the sharing economy will give higher or lower prices. Our impression is that the sharing economy's effect on cost has been bigger than the effect on quality. In other words, the sharing economy has generally led to lower prices. This is for example the case for the large initiatives in the markets for transport and housing. If it was quality that dominated, the sharing economy would lead to higher prices in the market. 
To what extent the sharing economy takes market shares from existing companies and to what extent it expands the market is closely related to the effect it has on the market price. When the price goes down, parts of the existing market are taken by the sharing economy. All else equal, the more the price goes down, the larger market share the sharing economy takes. In the interviews with sharing economy companies in Norway (Vista Analyse, 2016), many claimed they did not take business from incumbents but rather created new markets and reached new costumers. The companies in the traditional economy may disagree with this. In the theoretical framework, the sharing economy companies claim is that the demand curve is price elastic. If the demand curve is price elastic, one would expect a small change in price. If the effect on price is small, then a price inelastic supply curve is what would lead to a small change the market share of the incumbents.

Whether or not the sharing economy is taking business from the incumbents depends partly on how much the price changes and how inelastic the supply curve is. We do not know the empirical estimates of the supply curve in for example the taxi or hotel market in the Nordic countries. We expect it to be more inelastic in the short term than the long term. In the short term, many of the companies on the supply side, for example hotels and taxi drivers, will continue as usual even if their income goes down. In the long term however, they adjust by not building new hotels or finding new jobs instead of driving a taxi.

Economic growth will also affect the market shares, in absolute terms. But in relative terms the competition between the sharing economy and the traditional economy remains the same. Meaning that the sharing economy could be taking business from the incumbents even as the incumbent's revenue increases, because their revenue might have been larger if the sharing economy was not there and there was still economic growth.

The sharing economy is characterized by having network effects. This entails that the benefit depends on others use of the platform. There could be network effects from one initiative controlling the whole market by everyone using their platform as a marketplace. This depends on whether the market is able to realize the network effects. There is reason to believe that the network effects differ from market to market. 
Figure 7: The case of little competition with existing companies

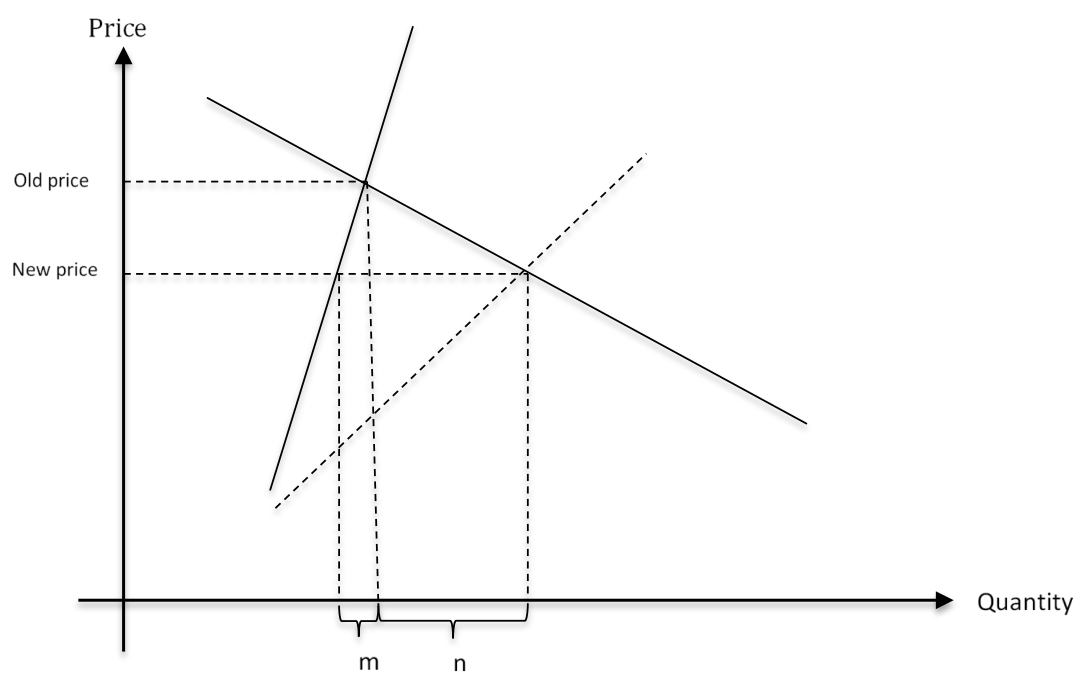

Source: Vista Analyse (2016).

Explanation: In the figure, we have assumed that the demand curve has not shifted since the effect on price seems to dominate. However, we have assumed an elastic demand curve. Given the effect on price, the market share taken from the incumbents by the sharing economy is smaller the steeper the original supply curve is around the earlier market point.

To what extent the initiatives compete with traditional initiatives is an empirical question. In the 2016 study of the sharing economy in Norway we did not have enough data to pinpoint the number in each segment. However, we found evidence that there were two effects; the new initiatives where creating new costumers/expanding the market, as well as taking customers away from traditional companies. We could not say how large the effects were, but the experts in the panel of that study expected the sharing economy's share of the economy to rise (Vista Analyse, 2016).

There are several factors that affect the market development of the sharing economy:

- Preferences/attitudes. Preferences/attitudes toward the modern sharing economy affect the size of the sharing economy. This would entail a shift in the demand curve, and if it is positive would lead to higher demand (but also to higher prices).

- Technological development. Technological development of sharing economy platforms affects the size of the sharing economy. It affects the shift in the supply curve, since better technology would lead to lower costs. 
- Public regulations. Public regulations of the sharing economy and the markets they operate within affect the sharing economy. If the sharing economy is regulated more harshly, the size of the shift in the supply curve will likely be smaller since they lose some of their cost advantage.

- Unemployment and inequality. Unemployment and inequality in society affect the size of the sharing economy. Unemployment reduces the opportunity cost of offering your time and skills in the sharing economy. It would increase the shift in the supply curve. Inequality could, all else equal, lead to an increase in individuals that are dependent on economizing on their resources. This could increase the sharing economy through a shift in the supply and demand curve. In the Nordic countries, the unemployment is low and inequality is small, but this could change with immigration, education, the system for wage negotiations, taxes and the general societal development.

- Urbanization. The degree of urbanization affects the size of the sharing economy. Both the demand curve (through the accessibility of costumers etc.) and the supply curve (through the accessibility of cars etc.) could shift outwards. An article by Cohen and Kietzmann (2014) emphasizes this in the transportation market. In the Nordic countries people live relatively spread out compared to other countries, but urbanization is rising also here. This could over time increase the market for the sharing economy.

\subsubsection{Possible negative effects of the sharing economy}

The sharing economy might have negative effects on the economies they are a part of. The negative effects relate to how the sharing economy fits into to the current rules and regulations. The sharing economy might affect:

- Worker's rights.

- Consumer's rights.

- Taxation.

- Private information/personal data.

We have referred to the fact that sharing economy initiatives can offer services at a low price. This is because of the utilization of underutilized resources. However, there might also be cost savings related to the service not being/fully being taxed, or because rules regarding competition, rights or personal information are not being followed. 4

Many of the initiatives do not fit clearly into the current regulatory framework. When the initiatives are small this might not be a big problem, but as the initiatives grow, the companies and the lawmakers have to solve what rules and regulations apply

${ }^{4}$ A working document by Einav et al. (2016) reviews some of these aspects in more depth. 
and how. The fact that the transactions take place on digital platforms makes taxation and regulation easier that with traditional businesses.

It seems that so far many sharing economy initiatives are regulated lighter than their traditional counterparts. For example, hotels must comply with more rules than a host on Airbnb. Whether this is right, or whether they should be put under more strict regulation is up to the governments of each country to decide. Another opportunity is that the introduction of these new actors may change the current regulation for the incumbents. The new competition may challenge outdated regulations or unfair market advantages in some markets and in that way, introduce new, healthy competition.

There has been some pushback in the Nordic countries because of fear that the new companies do not comply with legal standards and/or that they undermine the legal and regulatory standards. The future of the sharing economy depends on many factors, such as cultural and legal developments. However, the business model and the technological capabilities provide a clear advantage for some form of sharing economy. 



\section{Nordic sharing economy initiatives}

In this chapter, we give an overview and a description of some of the sharing economy initiatives in the Nordic countries. We present the different markets and describe some of the international companies as well as initiatives from the Nordic countries in each segment.

\subsection{The Norwegian study}

In our study of the Norwegian sharing economy from 2016, we identified around 50 initiatives in Norway (Vista Analyse, 2016). Most of the initiatives where founded within the previous 2-3 years. We estimated that the sharing economy revenue was around NOK 500 million in 2015. This is approximately 0.16 per mille of the total Norwegian economy (GDP) in 2015. Furthermore, in collaboration with a panel of experts, we estimated that the sharing economy could have a revenue of NOK 42 billion in 2025 . This is approximately $1.1 \%$ of the expected total Norwegian economy in $2025 . .^{5}$ This entails a growth of around $60 \%$ a year for the sharing economy in Norway (Vista Analyse, 2016).

We found the largest part of the sharing economy to be in the housing market and the transportation market, with Airbnb and Uber being the most prominent companies. Most of the companies are commercial, in the sense that people using the platform pay for the services they receive and that the company behind the platform is for-profit. However, there are some initiatives that are non-commercial. Some initiatives are idealistically motivated and want to promote true sharing without any form of payment. Probably the largest and most successful of this kind is Couchsurfing, but usually these initiatives tend to be rather small. Another non-commercial model is the co-ownership model. There are for example four large car collectives in Norway. Here the members pay for use, but only as a way of covering costs, since the initiative is a non-profit one. 
The sharing economy business model, with a company running a digital platform that connects supply and demand, typically produces few but large winners and many small challengers. The challengers are often new companies, with little or no profit. Out of the 50 sharing economy companies identified in the Norwegian study, the majority had very little revenue. 12 companies had more than NOK 5 million in revenue, while the largest company had NOK 200 million in revenue in 2015 . The reason is that there are network externalities, meaning that the platforms are a form of natural monopolies, where the value of the service depends on the number of people using it. There are some prominent companies, however most of the sharing economy initiatives are small and will probably disappear since there is likely just going to be one large player in each market. Some initiatives are international, however there were mostly Norwegian initiatives in the study (Vista Analyse, 2016).

\subsection{The sharing economy in the Nordic countries}

We have identified around one hundred sharing economy initiatives in the Nordic countries. This is by no means an exhaustive list, but gives an idea of the size and range of sharing economy initiatives that are active in the Nordic countries today.

Figure 8 gives an overview of the identified companies in each segment. The housing segment is probably the largest segment of the sharing economy in terms of economic activity. Airbnb has established itself as the biggest company and has activities in all the Nordic counties. There are most companies in the car and transportation segment. This is a segment with a valuable capital good that is underutilized, and there are many different types of transportation services. There are also many sharing economy initiatives in the services segment. Some facilitate services of all kinds, while others are focused on one area or type of service. The segment containing the initiatives that do not fall under any of the other segments include facilitation of small capital goods, parking and food related sharing. 
Figure 8: Overview of some identified companies in each segment in the Nordic countries
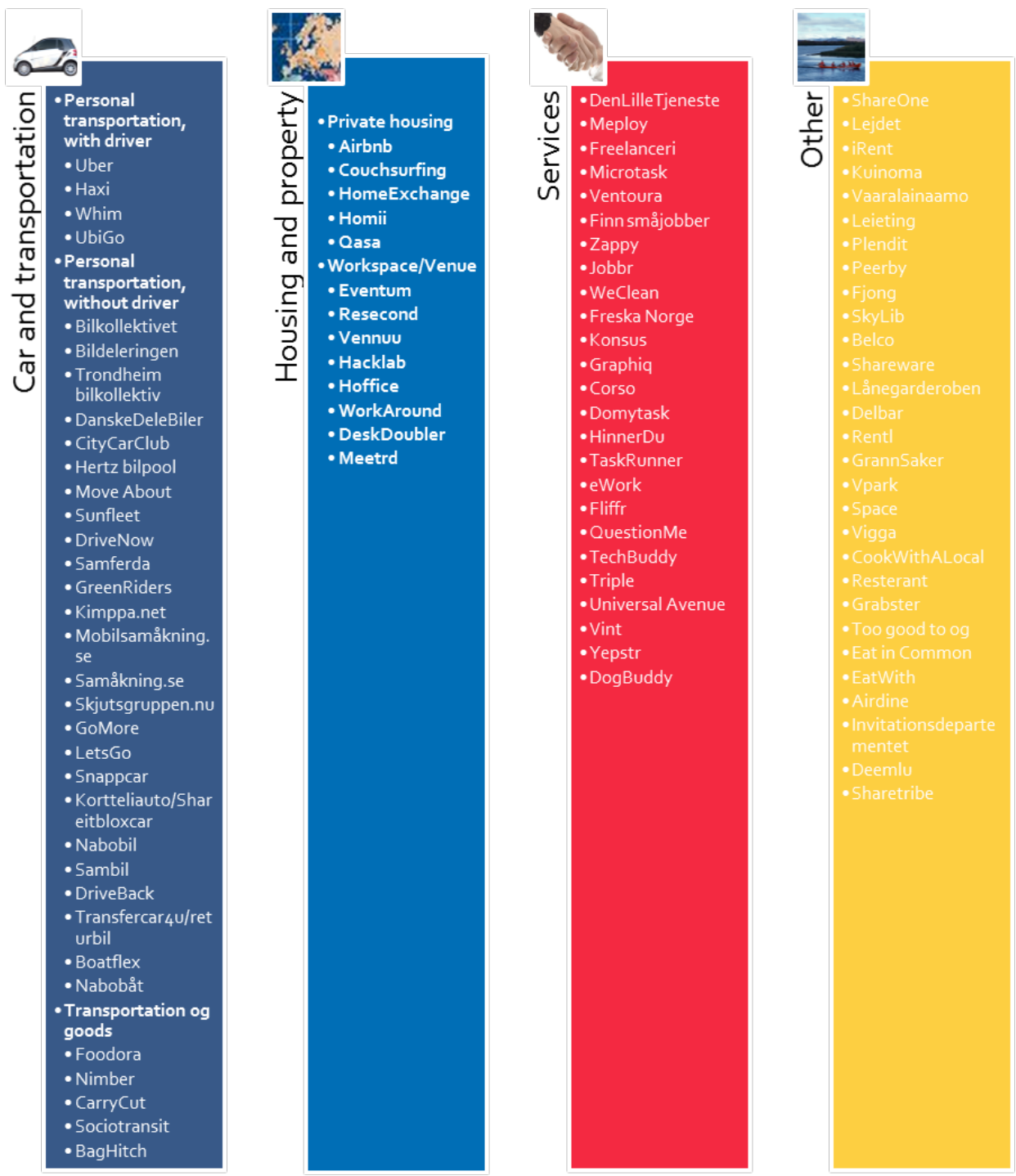

Source: Vista Analyse. 
Figure 9: Overview of some identified companies in each of the Nordic countries
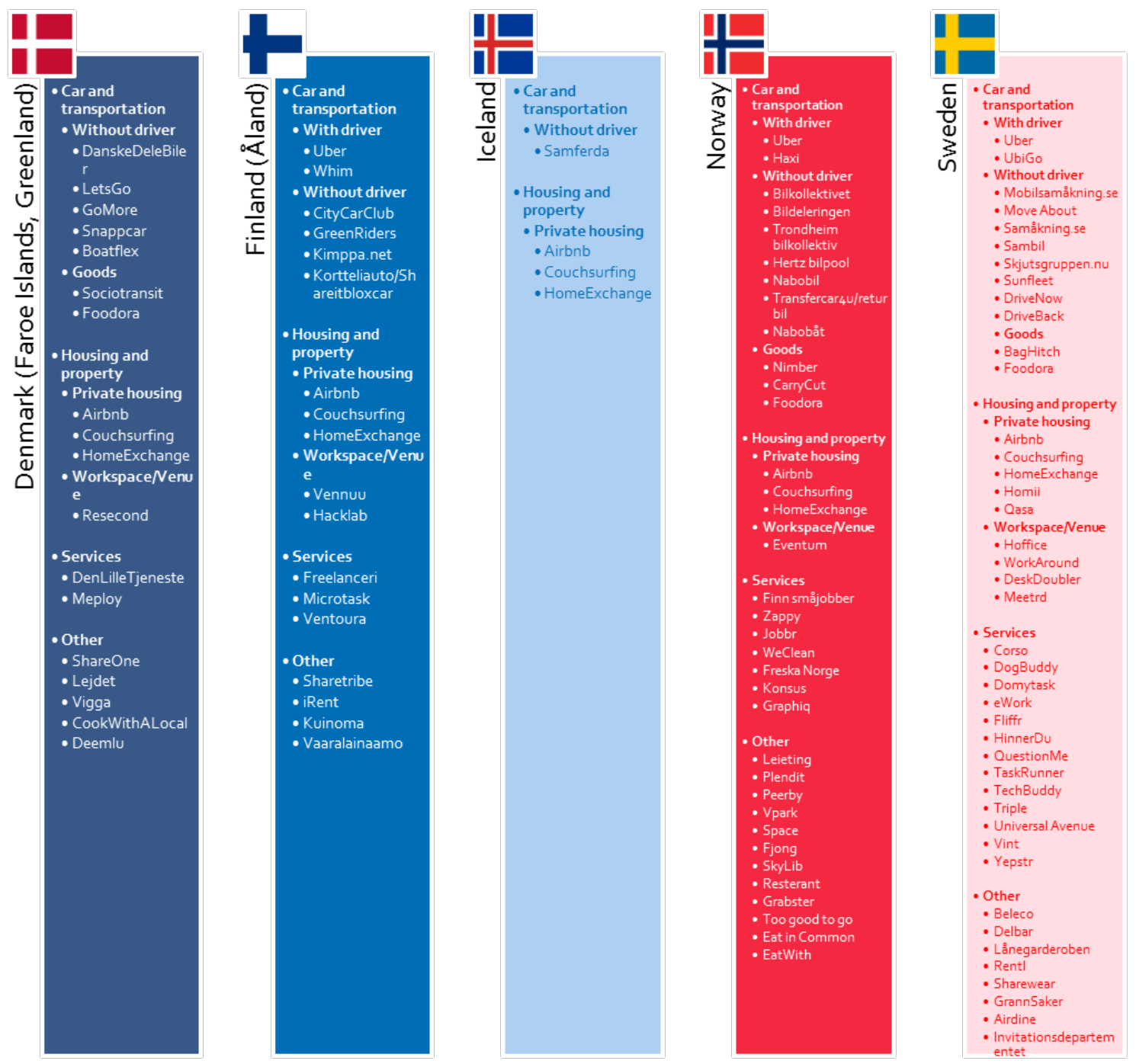

Source: Vista Analyse. 


\subsection{Car and transportation of people}

We have divided the category transportation into three segments, personal transportation with driver, - without driver and transportation of goods. In the following we present some of the initiatives within the three segments.

\subsubsection{Personal transportation with driver}

Internationally, there are several large sharing economy companies for personal transportation with a driver. Uber is the only one that is present in some of the Nordic countries. They are ride hailing services similar to taxis, but where people can use their own car to drive other people. Users plot in their location and destination, and the platform matches the users to drivers willing to drive them for a pre-specified price. There are other companies that focus more on ride sharing, where people that are traveling the same distance can carpool instead of taking separate cars. An example of this is the French company BlaBlaCar.

The market for transportation with driver is regulated in the Nordic countries under the laws concerning taxi business. The arrival of these new types of sharing economy services has created a lot of debate around the legality of these services as well as the need to reform the current laws and regulations.

The platforms compete with the taxi industry, and have in many cases taken market shares through lower prices in addition to the functionalities that are offered through their apps. Some taxi companies have been quick in offering similar applications with similar functionalities to match the competition.

Uber is present in Norway, Sweden and Finland. They used to be in Denmark as well, but have ended their presence there after some legal and cultural pushbacks. There is no Uber in Iceland. Uber is an online platform that facilitates transportation/rides between passengers and Uber-affiliated drivers. Users need a smartphone to use the service, since the platform uses information about their location. The passengers and drivers have different types of applications. The drivers use their own cars. Uber has launched different types of services; Uber POP is with regular cars, Uber BLACK is a limousine service, Uber EL is with electric cars and Uber XXL is with larger cars. In the US, they have launched Uber RUSH for transportation of goods and Uber EATS for delivery of takeaway food from restaurants. One of the fastest growing services they offer is Uber POOL, which is a service based on cars picking up several passengers going the same direction. According to Uber, it has already saved American cities for millions of transport kilometers and thousands of tons of $\mathrm{CO}_{2}$ emissions as an effect of Uber POOL's success.

The users have profiles and both passengers and drivers rate each other after each trip. Uber handles the payment on their platform and takes a cut of $20 \%$ of the price of the transaction. An algorithm calculates the prices based on time, distance and other factors. To balance supply and demand, Uber uses something called surge pricing. This is a form of dynamic pricing, where an algorithm can temporarily increase the price in an area where there is high demand compared to supply of available cars. This has a 
double effect, first and foremost that available drivers drive toward the area with high demand, since they get more paid for driving in that area. In addition, some passengers will wait until the price has gone down or find alternative forms of transport. When surge pricing is utilized it is clearly presented in the application.

According to The Economist (2016) Uber is in 425 cities in 72 countries all over the world. They have ambitions of further growth. And they are engaged in the development of self-driving cars. According to Uber they would like to be regulated in the same way as other actors in the economy, but the regulations should be at a minimum level and open to the usage of new technology to secure consumer safety and safety for the users of the platform.

Haxi facilitates transportation services between its users across their platform. It is a marketplace where passengers and drivers are matched. People that own a car and want to be a driver can sign up on the platform. Passengers can find a driver or request a driver for a certain trip, and then be contacted by a driver that wants to take them. Communication and payment between passengers and drivers happens across the platform. All users have profiles with recommendations from other users that have been in contact with them on the platform.

Haxi is different from Uber in that they do not set prices on travel routes. This is agreed upon between the users that have gotten in touch with each other on the Haxi platform. According to Aleksander Soender, the CEO of Haxi Norway, they are promoting carpooling and is not a form of taxi service and charge no fees from their users.

Haxi was established in 2013 by a group of engineers from Finland, Norway and Denmark. They had previously worked on a sharing system for longer travels, but it was difficult to establish a critical mass for the service to work well. After looking at other opportunities they discovered that in many places the access to taxis was low and the price was high. They therefore developed Haxi, that quickly became a success. The service is based on an established routine of people agreeing on social media to drive each other.

Haxi is present in Norway, Sweden and Iceland, but is largest in USA. While Uber has focused on densely populated cities. Haxi has focused on markets in areas that are less densely populated. Haxi is partly a competitor to traditional taxis. According to Aleksander Soender, Haxi has focused on a market that the traditional taxi industry does not cover, and therefore they are expanding the market.

Whim is an application that organizes travels across different modes of transportation. It optimizes travel routes and gives the user options. It also integrates the payment as a monthly fee. The app is a product of Maas Global, a company based in Helsinki. Whim is the world's first all-inclusive mobility service. They are launching the app in Helsinki and in West Midlands, UK.

UbiGo offers mobility as a service through a mobility subscription across different modes of transportation. Public transportation, car sharing, rental car service, taxi and bicycle systems are all in one app with one payment system, support and bonus points for sustainable choices. They have had a pilot in Gothenburg with 70 households for half a year, and are preparing a launch in Stockholm at the end of the year. Chalmers is a partner in the project and has published papers based on a thorough evaluation. 


\subsubsection{Personal transportation without driver}

There are many sharing economy companies that facilitate transportation without a driver. These are companies that enable car sharing, pooling or renting across digital platforms. Some of these are closely related to what traditional car renting companies do, which fall outside our definition of sharing economy activities from chapter 2.

The companies can broadly be placed in three categories: car collectives, carpooling and private car renting. Then there are some initiatives that match cars that need to be transported and drivers who also need to travel the same distance. There are also companies dedicated to matching the renting of privately owned boats.

Car collectives are collectives where all the members own and share the cars together. There are also some car rental companies that have made their way into this market by utilizing new technology and making it easier for people to share/rent cars for shorter trips. In these cases, the cars are owned by the company.

Bilkollektivet, Bildeleringen and Trondheim bilkollektiv are all Norwegian car collectives with their headquarters in Oslo, Bergen and Trondheim respectively. They are organized in a similar way, where the members own the cars collectively and pay according to their use. They have existed since the middle of the 1990s. The members can book the cars through digital platforms. People become members by buying a share and paying a deposit and a yearly fee. They then have access to the cars and can book and pay according to their use. The cars are placed in pre-specified places, where the members pick up and park the cars within the time frame they have booked the car for. The car collectives have a few employees to handle the operations of the cars and the digital platform.

Below we present an overview of companies that own and operate cars that customers can rent through a subscription-like arrangement, that largely looks like the car collectives. The members pay a deposit and a monthly fee for access to the cars that are rented according to a time and distance price related to the actual use. The difference is that the members are not owners and does not have the same responsibility or control as the owners in the car collectives.

DanskeDeleBiler is a Danish company that allows users to rent cars from each other as well as owning shared cars that members can rent. LetsGo is a similar Danish company that gives members access to their pool of cars in a number of Danish cities. City car club is like a car collective, but owned by a private company in Finland. Hertz bilpool in Norway owns cars in many cities that members can use against a fee. Move About in Norway focuses on electrical cars with designated locations where the cars can be charged. Sunfleet exists in many places in Sweden, and members can rent the cars for shorter time periods. DriveNow is an application for car renting. BMW, MINI and Sixt own the cars and run the service. Among the Nordic countries they cover Denmark and Sweden.

Carpooling is when people that are going the same way decide to ride in the same car instead of driving separate cars or travel by other transportation modes. Some of the platforms are more advanced with user profiles and reviews as well as other functionalities for finding and matching with other users, depending on where, when and other preferences. Other platforms are simpler with the main functionality of 
offering or requesting a ride for a certain trip at a certain time. Then other users that are interested can get in touch with them on the platform. Carpooling can be organized for a single trip or regular trips.

Samferda is a carpooling platform in Iceland. In Finland, there are two carpooling platforms, GreenRiders and Kimppa.net. In Sweden, there are several carpooling initiatives, like Mobilsamåkning.se, Samåkning.se and Skjutsgruppen.nu.

Private car renting are platforms where one can rent a car, but where the cars are rented out by private individuals. The following are all companies that organize car renting between private people. The organizing happens on their digital platforms that match people who want to rent out their car, and people who want to rent a car at the relevant time, cost and place. The companies do not own any of the cars themselves, but put the users into contact. The users have profiles where they can describe the car and/or person and it is possible for other users to write reviews. There are functions on the platforms to find the right car according to location, price and type. The whole transaction is done across the platform.

GoMore is a Danish company that organizes carpooling and leasing of cars in addition to car renting between private individuals. Snappcar is from the Netherlands, but they exist in Denmark and Sweden as well. In Finland there is Kortteliauto/Shareitbloxcar. In Norway there is Nabobil, and in Sweden there is Sambil.

DriveBack is a Swedish company. On their platform users can post cars that need to be transported from one place to another. Other users that wish to travel the same distance can drive the car and in that way both the car and the person gets transported for free. In Norway there is a similar platform called Transfercar4u/returbil.

Boatflex and Nabobåt are platforms where private people can rent out their boat when they don't use it, similar to the private car renting initiatives. Boatflex is a Danish company, while Nabobåt is Norwegian and affiliated with Nabobil.

\subsection{Transportation of goods}

There are some sharing economy companies that exclusively facilitate transportation of goods in the Nordic countries. There are also several initiatives that facilitate services, where one of the services might be transportation of goods. We will get back to those companies in the next subchapter. Also, Uber and other on demand transportation apps are moving into transportation of goods. It is possible that this area of the sharing economy will increase over time.

Foodora is a service for delivery of take away food from restaurants. The platform facilitates the sale of take away food from restaurants that cooperate with Foodora, and match the delivery service with a Foodora delivery cyclist.

Foodora is an international company that was started in Munich in 2014. Among the Nordic countries Foodora is in Norway, Sweden and Finland. Foodora can be regarded as competition to the restaurants that organize delivery on their own, typically pizza- and other fast food restaurants. But in the Nordic countries where food delivery has been relatively small, Foodora has expanded the market. They work with restaurants that 
previously did not do home delivery, and the business model utilizing a digital platform and people on bicycles means they can offer home delivery at a low cost.

There are several sharing economy companies that focus on the transportation of goods with a similar model. They run a digital platform that matches people that want an object carried from one place to another with people who are traveling that route and is willing to bring the object with them. People who want an object transported can post the task on their platform, with a description of the object, the location and destination, as well as the price for the assignment. People who are travelling the same route can contact them and get paid for the job. The users decide the practicalities regarding pickup and delivery. The companies handle the transactions across their platform and take a part of the price as a fee. All the users have profiles where other users can write reviews. All the transportation assignments on the platforms are insured.

They are competing with traditional logistics companies, but are focusing on a part of the market that is not well served. They utilize the sunk cost principle, where the people that transport the goods have already paid for the journey. The price they get for carrying an additional object is just an extra bonus and does not have to cover the actual costs of the trip (just the inconvenience related to picking up and delivering the item). In a way, they are utilizing the excess carrying capacity of travelers and giving them a chance to capitalize on that as well as people to send stuff more cheaply.

In Norway, there are two companies offering this kind of service; Nimber, which was established in 2010 and CarryCut that was established in 2016. Sociotransit is a Danish company established in 2017 that offers a similar service. BagHitch is a similar Swedish company.

\subsection{Housing and property}

\subsubsection{Private housing}

In the Nordic countries there are two significant international sharing economy initiatives in the housing sector, Airbnb and Couchsurfing. They facilitate short term rental or lending of a whole or parts of a residence between hosts and guests across their digital platforms. It is the sharing of the capital resource housing between mainly private individuals.

There are several international initiatives like these around the world, but we are not sure whether they have any substantial activity in the Nordic countries. Another international sharing economy company in this segment is HomeExchange. They have websites in all the Nordic languages, but it is not clear how much activity they have in the region.

Airbnb is a commercial company, where both the hosts and Airbnb themselves make money on the renting of housing on their platform. Couchsurfing on the other hand, started as a non-commercial initiative. They became a for-profit company in 2011 and makes money from, amongst other things, commercials on their website, but the hosts and guests do not pay for the accommodation that is organized across the platform. 
This sort of activity can have two effects. Firstly, one can imagine Airbnb and Couchsurfing taking customers form the hotel- and accommodation sector because they offer cheaper alternatives. Secondly, one can imagine that this new form of accommodation, through lower prices and a different offer, leads to more travel and subsequently more demand for accommodation.

There are some Nordic companies that operate in the same market, for example Homii and Qasa in Sweden. They are focused on renting apartments for longer periods, more like traditional apartment renting.

Airbnb is a sharing economy company for rooms and residences. It is a digital platform that matches people who would like to rent out their housing with people who would like to rent it. Airbnb is a complete marketplace with functionalities/features for uploading, searching for, discovering and booking accommodation around the world.

People who want to become a host on Airbnb can upload their room or residence on Airbnb's website/platform with a description and price. Potential guests can find and book the rooms through contact with and approval from the host on the platform. The platform has features to ensure the best possible match by location, price and standard. Additionally, both the hosts and guests have profiles where other users that have been in contact with them can rate and write reviews. The host's residence is protected by an insurance that covers damage up to one million USD. Airbnb handles the transaction between the host and guest. Airbnb takes a service charge of $6-12 \%$ of the price from the guests and a service charge of $3 \%$ from the host. ${ }^{6}$

Airbnb was established in 2008 and is based in San Francisco. They have had substantial growth since they started, and large amount of funding from investors. ${ }^{7}$

Airbnb does not want to go public with detailed information about their revenue and the value of transactions across their platform. But they have released key figures from their activities in several countries, including Norway in 2015. They are the largest initiative within housing and property in the sharing economy in the Nordic countries and probably in the world, but they are still a small part of the total hotel- and accommodation industry.

Airbnb compete against traditional hotel- and accommodation businesses. It is often claimed that Airbnb has a small impact on the hotel activity. It is challenging to quantify whether this is the case, but there is a study from the USA that claims that Airbnb has had a negative effect on the income of traditional hotels of around 8-10\% in the study area, Austin, Texas (Zervas et al., 2016).

Airbnb has grown rapidly and has a large user base. At the same time, they have met legal challenges in several cities related to the legality of the renting across their platform and other opposition related to taxation and gentrification - the process of locals being pushed out of their neighborhoods because of rising housing prices as an effect of the opportunity to rent out on Airbnb (Schneiderman, 2014). Airbnb has on the

\footnotetext{
${ }^{6}$ https://www.airbnb.no/help/article/104/what-are-guest-service-fees

https://www.airbnb.no/help/article/63/what-are-host-service-fees

7 https://en.wikipedia.org/wiki/Airbnb
} 
other side done studies to highlight the positive impacts of Airbnb activity for a neighborhood (Airbnb Action, 2016).

Couchsurfing is a service that matches its members to a global network of travelers. The platform can be used to get in contact with other members to arrange accommodation in their home. There are no formal criteria to host other members, but it is encouraged. Couchsurfing wants to connect people and promote travel and experiences. The members create user profiles where other members can rate and write recommendations to increase trust and ensure better matches. In addition to enabling accommodation, the platform is used to promote other forms of interaction between its members through events and sharing of knowledge.

Couchsurfing was founded in 2004 and began as a small idealistic initiative, but grew quickly and became a for-profit company in 2011. It is an international company and has more than 12 million members in over 200,000 cities. Based on the number of members and popularity as a concept and cultural phenomena, there are reasons to believe that there are many bookings across their platform. According to their website there are around 20,000 hosts in Norway, 6,000 in Iceland, 40,000 in Denmark, 30,000 in Sweden and 15,000 in Finland per April 2017.

HomeExchange is an international company that enables home exchanges or house swapping between its users. They exist under different names in all the Nordic countries; Kodinvaihtoloma in Finland, HemByte in Sweden etc. The users pay an annual fee to get access to the HomeExchange marketplace, and then get the opportunity to search and find homes to exchange for the users' own home for a specified period.

Homii and Oasa are both companies in Sweden. They focus on renting of apartments for longer time periods. They have a platform where users can post and find apartments. They facilitate matching of people, help with rental agreements and handle payments through the platform.

\subsubsection{Workspace/Venue}

There are several sharing economy companies in the Nordic countries that facilitate matching of workspaces or booking of venues for events. Some are Nordic companies, but there are also many international initiatives of this kind. It is possible that the latter ones also have activities in the Nordic countries, but not that we are aware of. This is an area that is growing and might potentially become a big part of the sharing economy in the Nordic countries in the future.

Eventum is a platform for renting venues for meetings and events. The concept has been called Airbnb for events. Users can post and find venues that can be booked on their platform. There are functions that allow for searching based on category, number of guests, price, time, location etc. The service was established in 2014 and is run by 7 employees. Eventum is based in Oslo, but enables renting of venues all over Norway. They have ambitions of growing in Norway and are considering expanding abroad. Eventum has several professional actors on the supply side who can offer other services in addition to the venue like catering and cleaning. According to Eventum this is a 
traditional market where people had to find venues by recommendations or looking them up in the phone book.

Resecond is a Danish sharing economy community. They offer a shared workspace with access to venues and other sharing economy benefits. They are located in Copenhagen. They also have a sharing community where members swap clothes and other things.

Venuu is a Finnish company and platform for booking venues, and is similar to Eventum in Norway. They have a Swedish branch as well.

Hacklab is a locally run workshop where people with common interests can work, study and play. Members pay a fee to cover the cost of the workshop and can use the facilities to work on different projects.

In Sweden, there are several sharing economy initiatives in the event and property segment. WorkAround is like Airbnb for office spaces. People can use the platform to find and rent a space in an office or rent out spare office space. WorkAround is a Swedish company and they have hosts in several Swedish cities as well as in Copenhagen. DeskDoubler is also a platform for renting offices spaces. Meetrd is similar to the other platforms, but focuses on matching rooms for meetings/events. Users can sign up and book rooms for their meetings. Another Swedish initiative has a bit of a different concept. Hoffice started in 2013 and is a platform that allows people to work together in each other's homes. It is a structured working environment where people that do not have a workplace can join a working group that takes place in one of the participant's homes. The service utilizes people's underutilized homes during the daytime, and uses it as a workspace where people can come together and have the benefits of a shared workspace.

\subsection{Services}

There are many sharing economy companies that offer matching of services in the Nordic countries. A theoretical dividing line between different services are those that can be done remotely and those where the user must be present to perform the service. This is relevant to the amount of international competition these companies are exposed to and other effects on the economy in general, including environmental impacts. We have not classified the companies on either side of this line because it is in many cases difficult to draw the line, but we mention the principal difference.

The services that demand physical presence are typically smaller manual jobs, and the companies put the users in contact on their digital platform. This can be jobs like cleaning, building, maintenance, shopping etc. These are jobs that people previously had to do themselves or get help from others through other channels. The platforms increase the access to people who are willing to do the job, and it is a marketplace where people can do small jobs for money. The users' platforms have profiles with descriptions of themselves and jobs that they have done, where other users have rated their work and written reviews/recommendations. There are several 
international sharing economy initiatives of this kind, like TaskRabbit, but they are not present in the Nordic countries.

There has been a lot of growth in these types of services and it is difficult to compare it to the traditional labor market. The digital platform lowers the transaction costs and makes a lot of services viable for outsourcing that previously would not have happened because of high transaction costs. When it comes to carrying out services in the sharing economy in the Nordic countries, there are a lot of challenges related to taxation and workers' rights and regulations. (FAFO, 2016)

There are also many sharing economy companies that facilitate the matching of non-location specific services. These are services where the person doing the job does not have to be at the same location as the person requesting it. These kinds of services are more open to foreign competition.

An important point regarding these services is the fact that people can do these services using the digital platform and make more money than they would be able to in their local labor market, but at the same time at a lower cost than in the labor market where the employer is requesting the service from. It is not only the difference in pay, but also the access to a larger market that enables better matching and the possibility of organizing the work in a more efficient manner. One of the main benefits of these platforms is the ease in which one can outsource work on them.

Outsourcing is already widespread and a natural part of a more globalized and specialized world. The companies do not do the services themselves, but run a platform that matches supply and demand for labor. In addition, these platforms can have functionalities that simplify the process or increase the quality of the service.

TaskRabbit is one of the biggest sharing economy companies for services. It is an American company that was founded in 2008. They are present in many cities around the US and in London.

In Denmark, there are at least two of these kinds of platform: DenLilleTjeneste and Meploy. In Finland there are Freelanceri and Microtask where people can put web or data capture services, and the work gets outsourced to freelancers. Ventoura is a digital application where locals can guide travelers.

In Norway there are a number of companies. Finn småjobber, which is a part of finn.no AS, was started in 2013 and matches services all over Norway. Zappy is a platform that since 2015 has facilitated smaller services. Jobbr is similar to Zappy. WeClean and Freska Norge are specialized for cleaning. Konsus is an on-demand freelance service platform where people can send tasks and pre-vetted experts will do the job immediately. Graphiq is specialized for graphic design jobs.

In Sweden, there is Corso- Driving instructors on demand, Domytask, HinnerDu, TaskRunner - small jobs, eWork - consulting work, Fliffr - Experts on demand, - small jobs, QuestionMe- Q\&A on demand, TechBuddy- Tech support on demand, TrippleVisitor experiences on demand, Universal Avenue- Sales force on demand, Vint - for personal trainers Yepstr- Help from neighbours on demand, Dogbuddy - For dogsitting. 


\subsection{Other}

There are a number of sharing economy initiatives that do not fall within the categories above. We will present the remaining identified initiatives in this subchapter.

There are a number of sharing economy initiatives that match people that want to rent out and people that want to rent various small capital objects. Larger capital goods like houses and cars have been discussed above.

ShareOne and Lejdet are such companies in Denmark. In Finland there are iRent, Kuinoma and Vaaralainaamo. In Norway there are Leieting, Plendit, Peerby and Fjong for clothes and SkyLib. In Sweden there are Beleco that rents out furniture, Sharewear and Lånegarderoben which focus on clothes and Delbar, Rentl and GrannSaker where you can rent everything else.

There are a few sharing economy initiatives that match parking spaces for cars. Both Vpark and Space in Norway facilitate renting of parking spaces.

In Denmark there are several initiatives that facilitate the sharing of clothes. Resecond, which was mentioned above relating to their shared working spaces, also facilitate swapping of clothes and things, primarily dresses, between its members. Chare was a company that also facilitated the sharing of clothes, but it was dissolved in 2015 because of lack of funds. The business model was that members paid a monthly fee and transaction costs related to the washing of clothes. They could rent as many clothes as they wished, and deliver them within 14 days. Vigga is a Danish company that offers a subscription to baby clothes. Its costumers borrow baby clothes, and rotate the wardrobe as the baby grows. The smaller clothes are used by other subscribers.

There are a number of initiatives that are related to food. CookWithALocal is a sharing economy platform where people can offer to host or attend food and beverage events worldwide by meeting up and cook or taste food together. The company was founded in Denmark in 2014. In Norway, Resterant, Grabster and Too good to go all facilitate food preparation services, while Eat in Common and EatWith match people that would like to eat in common. Airdine is a Swedish company that connects users that like to cook with users looking for a place to dine. Invitationsdepartementet is a similar service, but the point is to connect people that would like to learn Swedish with people that speak Swedish fluently over a homecooked dinner.

Deemlu is a platform that collects all the users rating from different platforms, letting people leverage their trustworthiness online. It is not a sharing economy initiative per se, but is closely related to the sharing economy by letting people leverage their trustworthiness.

Sharetribe is a Finnish company that helps companies build marketplace websites online. The digital platform that they help users create is the basis for sharing economy companies. 


\section{Some numerical illustrations of emission reduction potentials}

This chapter will provide some numerical illustrations of the potential environmental effects changes in consumer behavior from various sharing economy initiatives could lead to. For simplicity, the focus of this chapter is on potential changes in emissions of $\mathrm{CO}_{2} \mathrm{e}_{1}^{8}$ however it should be noted that sharing initiatives also could have impacts on local air pollution, acidification etc. Particular attention has been devoted to transportation because the body of literature on potential effects on emissions is considerably larger for this sector than for the other sectors.

\subsection{Transportation}

As described in chapter 3 , there are several types of sharing initiatives related to transportation. Car-sharing, which provides short term access to cars, is distinct from ride-hailing services, where customers are being driven. Uber and GoMore are examples of ride-hailing services. This section will focus on the potential environmental effects of car-sharing. One might, however, expect ride-hailing to have some similar environmental impacts to car-sharing. The key difference between car-sharing and ride-hailing is that car-sharing utilizes the spare capacity of cars when they are not being used, while ride-hailing utilizes the spare passenger capacity of cars. Another example of the latter is ride sharing, where people that are traveling the same distance can carpool instead of taking separate cars. In both cases, the environmental impacts will largely depend on changes in consumer behavior.

Car-sharing includes business-to-customer services and peer-to-peer services. The business-to-customer services generally involve that cars are available at fixed locations throughout metropolitan areas. Examples of such organizations are the Danish DanskeDeleBiler and Bilkollektivet in Norway. Peer-to-peer services allow people to rent cars directly from car owners (e.g. the Norwegian Nabobil). Car-sharing is most common and best suited in urban areas with access to public transportation. Studies have shown that around $95 \%$ of car-sharing members live in cities (TØI, 2011).

\footnotetext{
${ }^{8} \mathrm{CO}_{2} \mathrm{e}$ (carbon dioxide equivalent) is a measure of greenhouse gases emitted when humans undertake certain activities. In addition to $\mathrm{CO}_{2}$, the measure includes other greenhouse gases such as methane, nitrous oxide and ozone, expressed in terms of $\mathrm{CO}_{2}$ based on their relative global warming potential.
} 
The remainder of this section is structured as follows:

- Subsection 4.1.1 provides a short description of environmental impacts of personal vehicles (from production, through use and final disposal).

- Subsection 4.1.2 presents the key factors that can determine the environmental impacts of car-sharing, with numerical examples.

- Subsection 4.1.3 summarizes the findings in terms of overall environmental impacts.

\subsubsection{Environmental impacts of personal vehicles}

Nemry et al. (2008) estimate the life-cycle environmental impacts of a typical personal car in Europe. ${ }^{9}$ Life-cycle environmental impacts include both the direct and indirect processes and services required to operate a vehicle.

The life-cycle phases include:

- Car production (raw material extraction, material transformation and car assembly).

- Replacement and spare parts production (tyres, battery, lubricants and refrigerants).

- Fuel transformation process upstream to fuel consumption (well-to-tank - WTT).

- Fuel consumption for car driving (tank-to-wheel - TTW).

- Car disposal and waste treatment (end-of-life-EOL).

As already mentioned, this chapter will focus on the $\mathrm{CO}_{2} \mathrm{e}$-emissions, however the production, use, and disposal of a car also cause a range of other environmental impacts. For example, extraction, refining and transportation of crude oil lead to acidification, emission of particles $\left(\mathrm{PM}_{2.5}\right)$, eutrophication (which depletes water of oxygen), ozone depletion, and photochemical pollution (e.g. from $\mathrm{NO}_{\mathrm{x}}$ ).

Figure 10 presents the $\mathrm{CO}_{2} \mathrm{e}$-emissions from a typical petrol car, showing that most of the emissions stem from fuel consumption for driving (TTW), followed by the fuel transformation process (WTT) and car production.

\footnotetext{
9 The study considers two typical (or 'base case') car models - one petrol car and one diesel car - defined as those corresponding to the average characteristics of new cars sold in Europe, which primarily concern power,cylinder size and weight. These characteristics are summarized in table 7 on page 48 of Nemry et al. (2008).
} 
Figure 10: Life-cycle impacts of a typical petrol car

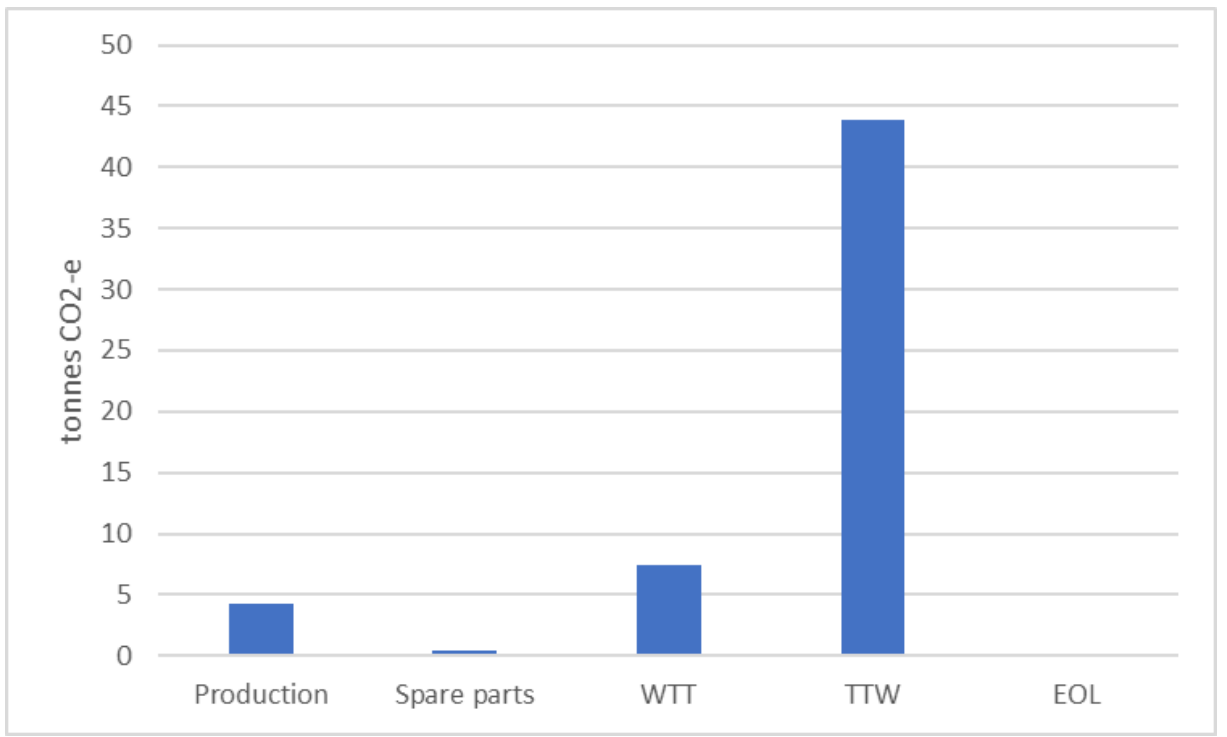

Source: : Nemry et al. (2008), p. 64. The impacts are similar for the base case diesel car.

\subsubsection{Key factors that determine the environmental impacts of car-sharing}

There are several factors which can determine the overall environmental impact of carsharing. According to the literature, the key positive environmental impacts from carsharing arise from changes in consumer behavior related to car ownership and the number of kilometers traveled by car. That is, on average people own fewer cars and drive less after becoming car-sharing members. ${ }^{10}$ This offers environmental benefits from reduced vehicle manufacturing, maintenance, use and disposal. As car-sharing members drive less, they might also increase their use of public transportation, which in turn could generate additional emissions. A reduction in vehicle holdings and the volume of motor transport can also reduce congestion and the demand for infrastructure, such as parking. In addition, the average shared car generally uses less fuel and emits fewer pollutants compared to the average personal car as the car-sharing fleets typically consist of newer and more energy-efficient cars.

At the same time, car-sharing may cause indirect rebound effects - meaning that if car-sharing members save money, they may spend their savings on other products or services, which in turn could lead to increased $\mathrm{CO}_{2}$ e-emissions or other negative environmental impacts. The environmental impacts from the indirect rebound effect will vary with the types of goods and services the consumer spends his/her savings on.

Each of the above-mentioned factors are discussed in greater detail below.

10 The studies that arrive at these results are presented in Tables 1 and 2 later in this chapter. 


\section{Car ownership}

Several studies have estimated the impact of car-sharing on personal car ownership. The results of these studies are summarized in Table 1 and show that households on average tend to reduce their vehicle holdings after becoming car-sharing members.

As defined by Martin and Shaheen (2016), there are two types of effects that can reduce vehicle holdings:

- Suppression effect: car-sharing removes the need for members to purchase a personal vehicle.

- Shedding effect: car-sharing allows members to sell or get rid of a personal vehicle.

Most of the studies in Table 1 have conducted surveys among car-sharing members, asking questions about their travel behavior, vehicle holdings etc. before and after joining a car-sharing organization. The surveys with the largest number of respondents are from North America.

While the studies find that car-sharing reduces personal vehicle holdings among car-sharing members, this may not directly translate into lower car sales. Boston Consulting Group (2016) have found that car-sharing will only have a small impact on future new-car sales because some share of lost car sales will be offset by sales into carsharing fleets. This phenomenon is attributed to the high turnover rates of car-sharing fleets. Shared cars are replaced more often than personal cars (typically every three years) because of the high utilization and subsequent wear and tear.

Boston Consulting Group (2016) predicts the number of vehicles that will be purchased for car-sharing fleets in 2021, as well as the share of foregone private purchases those sales will offset. They find that sales to car-sharing fleets in Europe will offset foregone car sales by approximately $35 \% .^{11}$

Based on the results of the studies in Table 1 , one shared car could replace approximately 4 to 13 personal cars. If this reduction is offset by $35 \%$ due to sales to carsharing fleets, the replacement rate would be reduced to around 3 to 8 personal cars.

Nemry et al. (2008) estimate that the production, maintenance, and disposal of a car generate approximately 5 tons of $\mathrm{CO}_{2} \mathrm{e}$-emissions. ${ }^{12}$ Using this estimate, and assuming that one shared car replaces 3 to 8 personal cars (eliminating the production of 2 to 7 cars), $\mathrm{CO}_{2} \mathrm{e}$-emissions from car production, maintenance, and disposal could be reduced by around 10 to 35 tons per shared car. Split evenly over an average life of a car of 12.5 years, ${ }^{13}$ the annual average reductions range from 0.8 to 2.8 tons of $\mathrm{CO}_{2} \mathrm{e}$.

\footnotetext{
${ }^{11}$ The report predicts that new-car sales in Europe will increase by 96,000 cars in 2021 because of sales to car-

sharing fleets, while private new-car sales will decrease by 278,000 cars. The resulting net decrease in new-car sales is 182,000 cars.

${ }^{12} 4.8$ tons $\mathrm{CO}_{2} \mathrm{e}$ for the base case petrol car and 5.3 tons $\mathrm{CO}_{2}$ e for the base case diesel car. See page 64 and 65 of Nemry et al. (2008) for complete summaries of the life-cycle impacts.

${ }^{13}$ This is the average life of cars assumed in Nemry et al. (2008).
} 
With 20 members per shared car, ${ }^{14}$ this would equal a reduction per member household by 40 to $140 \mathrm{~kg} \mathrm{CO}$ e per year.

As a comparison, one of the studies in Table 1 (Nijland et al., 2015), estimates the reduction in emissions that result from reduced car ownership. The study is based on a survey of 165 car-sharing members in the Netherlands. The researchers find that carsharing reduces emissions generated from vehicle manufacturing and demolition by 85 to $175 \mathrm{~kg}$ per member household per year..$^{15}$ This does, however, not consider the effect of new-car sales into car-sharing fleets described above. Reducing the estimates by $35 \%$, they become 55 to $114 \mathrm{~kg}$, which is within the range of 40 to $140 \mathrm{~kg} \mathrm{CO} 2 \mathrm{e}$.

It should be noted that the estimate of 40 to $140 \mathrm{~kg}$ is only a rough approximation used to illustrate the potential environmental benefits from car-sharing. The size of the reduction of $\mathrm{CO}_{2} \mathrm{e}$-emissions will vary with the underlying assumptions. For example, Concito (2010) reviews a range of different input-output studies and finds that $\mathrm{CO}_{2} \mathrm{e}$ emissions from the production and maintenance of a car could be as high as 16 tons. Emissions will also vary greatly with the type of car that is being produced.

Table 1: Impact of car-sharing on personal car holdings*

\begin{tabular}{|c|c|c|c|}
\hline Study & Country/region & Results & Data sources \\
\hline $\begin{array}{l}\text { Martin and } \\
\text { Shaheen (2016) }\end{array}$ & $\begin{array}{l}\text { USA and } \\
\text { Canada }\end{array}$ & $\begin{array}{l}\text { Each car2go vehicle removed between } 7 \text { to } \\
11 \text { vehicles from the road of the five cities } \\
\text { studied (on average). }\end{array}$ & $\begin{array}{l}\text { Survey of car2go members in } \\
\text { Calgary, San Diego, Seattle, } \\
\text { Vancouver, Washington, D.C. with } \\
6,167 \text { responses. }\end{array}$ \\
\hline Nijland et al. (2015) & Netherlands & $\begin{array}{l}\text { Car ownership decreased by } 33 \% \text { compared } \\
\text { with the period before becoming car-sharing } \\
\text { members. }\end{array}$ & $\begin{array}{l}\text { Survey of } 165 \text { car-sharing } \\
\text { members in the Netherlands. }\end{array}$ \\
\hline Concito (2015) & Denmark & $\begin{array}{l}31 \% \text { of car-sharing members reported that } \\
\text { they would have purchased a car if they } \\
\text { were not members. }\end{array}$ & $\begin{array}{l}\text { Survey performed by the Danish } \\
\text { car-sharing provider Letsgo } \\
\text { among its members. }\end{array}$ \\
\hline ТØI (2011) & Norway & $\begin{array}{l}25 \% \text { owned fewer cars after becoming } \\
\text { members. } 40 \% \text { would most likely have } \\
\text { purchased a car had they not joined } \\
\text { Bilkollektivet. }\end{array}$ & $\begin{array}{l}\text { Survey of car-sharing members in } \\
\text { Bilkollektivet. } 742 \text { responses. }\end{array}$ \\
\hline Martin et al. (2010) & $\begin{array}{l}\text { USA and } \\
\text { Canada }\end{array}$ & $\begin{array}{l}9-13 \text { vehicles taken off the road for each } \\
\text { shared car. }\end{array}$ & $\begin{array}{l}\text { North American car-sharing } \\
\text { member survey with } 6,281 \\
\text { respondents conducted in } 2008 \text {. }\end{array}$ \\
\hline Momo (2010) & Europe & $\begin{array}{l}\text { Each newly-acquired, normally used car- } \\
\text { sharing vehicle replaces on average at least } \\
\text { 4-8 personal cars. }\end{array}$ & $\begin{array}{l}\text { Review of surveys undertaken } \\
\text { between } 2003 \text { and } 2009 \text { in } \\
\text { European countries. }\end{array}$ \\
\hline
\end{tabular}

Note: * All of the studies consider both the suppression effect and the shedding effect, except Concito (2015), which only considers the suppression effect.

Source: Vista Analyse.

\footnotetext{
${ }_{14}$ According to Concito (2015), Letsgo in Denmark has about 19 members per shared car. Bilkollektivet in Norway has approximately 20 members per shared car (300 cars and 6000 members).

15 Nijland et al. (2015) assume that 10 to $20 \%$ of the $\mathrm{CO}_{2}$ emitted during the lifespan of a vehicle is related to its production and demolition (e.g. see Gbeghaje-Das, 2013; Samaras et al., 2008), a vehicle lifespan of 15 years, and an average of 10 users per shared car.
} 
Furthermore, some of the estimates in Table 1 may not be applicable to a Nordic context. For example, transportation in the US is typically characterised by a higher reliance on personal cars compared to the Nordic countries.

\section{Vehicle operation}

Studies typically measure the net impact of car-sharing on the volume of personal motor vehicle transport by the change in kilometers traveled by personal cars (VehicleKilometers Traveled - VKT). ${ }^{16}$ Table 2 summarizes the results of studies that have estimated the impact of car-sharing on VKT and the subsequent reductions in $\mathrm{CO}_{2} \mathrm{e}$ emissions. The results show that households - overall - drive less after becoming carsharing members, thereby reducing $\mathrm{CO}_{2}$ e-emissions.

There are two main ways in which car-sharing may impact households' transport patterns, each with opposite effects on the volume of motor transport. Firstly, households that substitute their personal car with a shared car generally drive less. This could be attributed to shared cars being relatively less accessible (as the cars may be parked further away, it involves reserving etc.) and the per-trip costs being more apparent compared to personal vehicles. ${ }^{17}$ Secondly, some households that join carsharing drive more than before. That is, trips previously untraveled or traveled by other modes of transport, such as public transport, bicycling or walking, are substituted by trips in shared cars.

The studies in Table 2 found that most households joining car-sharing drive more than before. However, the increases in driving by these households are small compared to the decreases in driving by households that substitute their personal car for a shared car. The net impact is a decrease in the number of kilometers traveled.

Susan Shaheen and her colleagues at the Transportation Sustainability Research Center at UC Berkley in USA have published several articles on the topic of car-sharing. In 2008 they conducted a survey among car-sharing members in North America. ${ }^{18}$ The results, presented in Martin and Shaheen (2011), show a reduction in $\mathrm{CO}_{2}$-emissions of $840 \mathrm{~kg}$ per member household per year. Shaheen also conducted a survey among car2go members in five North American cities in 2014-2015, ${ }^{19}$ showing that car2go household VKT on average was reduced by 6 to $16 \%$ across all five cities studied, resulting in a reduction in $\mathrm{CO}_{2}$-emissions per car2go household of 4 to $18 \%$ (see Martin and Shaheen, 2016). The $\mathrm{CO}_{2}$-reductions found in the studies by Martin and Shaheen from 2011 and 2016 include changes in emissions that would arise from changes in caruse. The studies do not consider changes in emissions from changes in the production, maintenance or disposal or cars.

\footnotetext{
${ }^{16} \mathrm{VKT}=$ Number of Vehicles $\times$ Distance Traveled.

${ }_{17}$ Almost all costs of car-sharing are incurred on a per-trip basis, as opposed to personal car ownership where most costs are incurred upfront and there are only small costs related to driving.

${ }^{18}$ The survey had 6,281 respondents. The participating North American organizations in the survey included (a) AutoShare, (b) City CarShare, (c) CityWheels, (d) Community Car Share of Bellingham, (e) Communauto, (f) Community Car, (g) Co-operative Auto Network, (h) I-Go, (i) PhillyCarShare, (j) VrtuCar, and (k) Zipcar (in the United States and Canada). 19 Car2 Go operates as a one-way instant access car sharing system within a pre-defined urban zone. Members can find an unoccupied parked vehicle, use it, and park it again within the defined operating zone. The five cities were: Calgary, San Diego, Seattle, Vancouver, Washington, D.C. The survey received 6,167 responses.
} 
Nijland et al. (2015) conducted a survey among car-sharing members in the Netherlands. The survey results showed that car-sharing results in a net reduction of $90 \mathrm{~kg} \mathrm{CO} 2 \mathrm{e}$-emissions per household per year.

The results of Nijland et al. (2015) are notably lower than the $840 \mathrm{~kg} \mathrm{CO} 2 \mathrm{e}$ emissions reductions estimated by Martin and Shaheen (2011) - even though the percentage reduction in VKT is quite similar for the two studies. Possible explanations for the large difference could be that the average annual distance traveled by car and emissions per distance travelled are greater in USA than in the Netherlands. Thus, Nordic emission reductions are likely somewhat closer to the Dutch figure than to the US one.

Ryden and Morin (2005) conducted surveys among car-sharing members in Bremen and in Belgium. The results showed a reduction in car mileage by $28 \%$ in Belgium and $45 \%$ in Bremen. They assume this means a reduction in $\mathrm{CO}_{2}$ emissions by the sam

Table 2: Impact of car-sharing on vehicle operations

\begin{tabular}{|c|c|c|c|c|}
\hline Study & Country/region & Reduction in VKT & Reduction in $\mathrm{CO}_{2} \mathrm{e}$ & Data sources \\
\hline $\begin{array}{l}\text { Martin and } \\
\text { Shaheen (2016) }\end{array}$ & $\begin{array}{l}\text { USA and } \\
\text { Canada }\end{array}$ & $\begin{array}{l}\text { Across all five cities } \\
\text { studied the reduction in } \\
\text { VKT traveled by } \\
\text { personal car ranged } \\
\text { from } 6 \text { to } 16 \% \text {. }\end{array}$ & $\begin{array}{l}\text { Reduction in } \mathrm{CO}_{2} \mathrm{e}- \\
\text { emissions per car2go } \\
\text { household of } 4-18 \% \text {. }\end{array}$ & $\begin{array}{l}\text { Survey of car2go members } \\
\text { in Calgary, Dan Diego, } \\
\text { Seattle, Vancouver, } \\
\text { Washington, D.C. with 6,167 } \\
\text { respondents. }\end{array}$ \\
\hline $\begin{array}{l}\text { Nijland et al. } \\
\text { (2015) }\end{array}$ & Netherlands & $\begin{array}{l}\text { Car-sharing members } \\
\text { drove around } 15-20 \% \\
\text { less after becoming } \\
\text { members. }\end{array}$ & $\begin{array}{l}\text { Net reduction of } 90 \mathrm{~kg} \\
\mathrm{CO}_{2} \text { e per member } \\
\text { household per year. }\end{array}$ & $\begin{array}{l}\text { Survey of } 165 \text { car-sharing } \\
\text { members in the } \\
\text { Netherlands. }\end{array}$ \\
\hline $\begin{array}{l}\text { Martin and } \\
\text { Shaheen (2011) }\end{array}$ & $\begin{array}{l}\text { USA and } \\
\text { Canada }\end{array}$ & $\begin{array}{l}\text { The average observed } \\
\text { VKT per year declined by } \\
27 \% \text { after respondents } \\
\text { joined a car-sharing } \\
\text { organization. }\end{array}$ & $\begin{array}{l}\text { Reduction of } 840 \mathrm{~kg} \mathrm{CO} \mathrm{CO}_{2} \mathrm{e} \\
\text { per member household, } \\
\text { per year due to the } \\
\text { shedding effect }(580 \mathrm{~kg}) \\
\text { and the suppression effect } \\
(280 \mathrm{~kg}) \text {. }\end{array}$ & $\begin{array}{l}\text { North American car-sharing } \\
\text { member survey with } 6,281 \\
\text { respondents conducted in } \\
2008 \text {. }\end{array}$ \\
\hline $\begin{array}{l}\text { Ryden and } \\
\text { Morin (2005) }\end{array}$ & $\begin{array}{l}\text { Belgium and } \\
\text { Germany }\end{array}$ & $\begin{array}{l}\text { Car-sharing reduces car } \\
\text { mileage by } 28 \% \text { in } \\
\text { Belgium and } 45 \% \text { in } \\
\text { Bremen }\end{array}$ & $\begin{array}{l}\text { Reduction in } \mathrm{CO}_{2} \\
\text { emissions from reduction } \\
\text { in car mileage; } 28 \% \text { in } \\
\text { Belgium and } 45 \% \text { in } \\
\text { Bremen. }\end{array}$ & $\begin{array}{l}\text { Surveys undertaken in } \\
\text { Bremen ( } 301 \text { respondents) } \\
\text { and in Belgium ( } 272 \\
\text { respondents). }\end{array}$ \\
\hline
\end{tabular}

Source: Vista Analyse.

e amount.

Alternative modes of transportation

While car-sharing may reduce the distance driven by car, it may also increase the distance traveled by public transport. For a complete picture of the environmental impact of car-sharing, emissions from the increased use of alternative modes of transport (for example trains and buses) should be included, however few studies consider these effects. Ryden and Morin (2005) estimate that the change in public transport usage from car-sharing lead to an increase in $\mathrm{CO}_{2}$ emissions of around $2 \%$.

The amount of emissions from an increase in the use of public transportation will firstly depend on the size of this increase, and the mode of transport. Secondly, if the 
increase takes place mostly during peak hours, extra buses, trains etc. might need to be put into service. However, if the increase takes place off-peak, it is less likely to create additional transport.

\section{Parking infrastructure demand}

By reducing vehicle holdings and VKT, car-sharing also has potential impacts on infrastructure requirements, particularly parking. Few studies have quantified the magnitude of this impact. However, three are summarized in Chen and Kockelman (2016):

- A 2004 study in the UK surveyed employers and found that spaces fell from 0.79 spaces per staff member to 0.42 spaces per staff member after starting a carsharing program (Department for Transport, 2004).

- Looking at car-sharing and parking at the building scale in Toronto, Engel-Yan and Passmore (2013) found that buildings with dedicated car-share vehicles required 50\% fewer parking spaces than those without such dedications.

- Using survey data from Ithaca Carshare, Stasko et al. (2013) estimated that program participants' on-street parking needs or demands fall by 26 to $30 \%$, depending on day of the week and time of the day.

Furthermore, Ryden and Morin (2005) estimated that car-sharing reduces the need for parking space by $90-135 \mathrm{~m}^{2}$ in Bremen and $45-75 \mathrm{~m}^{2}$ in Belgium for each car-sharing car.

Energy consumption during use phase

The car-sharing fleets typically consist of newer, lower-emission cars compared to the average stock of personal cars. Momo (2010) found that car-sharing fleets register up to 15 to $20 \%$ lower $\mathrm{CO}_{2}$-emissions, in some cases up to25\%, compared to the average personal car. ${ }^{20}$ Based on survey responses from car-sharing members in Belgium, Ryden and Morin (2005) estimate that the average shared car consumes $17 \%$ less fuel-and emits $17 \%$ less $\mathrm{CO}_{2}$ - compared to the average personal car.

The higher fuel efficiency of shared cars may be attributed to a higher replacement rate (around every 3 years) compared to the average personal car, and car-sharing providers having incentives to choose fuel-efficient cars to reduce their costs (Concito, 2015). Several car-sharing fleets also have a higher percentage of hybrid or electric cars compared to personal cars. For example, $15 \%$ of the Letsgo shared cars in Denmark are electric.

Additionally, while personal cars often are purchased to handle the maximum capacity needed, car-sharing members can adjust their choice of car based on the situation in which the car is to be used and thereby lower their fuel use.

While the cars may be more fuel efficient, the fuel use and emissions from driving also depend on how the car is being driven. Concito (2015) argues that, as car-sharing

${ }^{20}$ Based on results from 10 surveys from various countries. Most of the surveys were conducted in 2008/og. 
members often are less experienced drivers, they may drive less economically and burn more fuel per kilometer compared to personal car owners.

\section{Indirect rebound effects}

Being a car-sharing member may offer some financial benefits compared to owning a personal car, at least for someone who does not use a car very often. When people save money, they may spend some of their savings on other products or services. This is called the indirect rebound effect. The environmental impacts from the indirect rebound effect will vary with the types of goods and services the consumer spends his/her savings on. For example, if a family decides to spend the savings on flight tickets for a holiday, this could more than offset the environmental benefits from car-sharing.

Whether someone will save money by joining car-sharing depends on what mode of transportation they otherwise would have used. Someone who chooses to use a shared car instead of going by bike will not save money, but someone who uses a shared car as a replacement for a personal car may indeed save money.

As an example, imagine someone who over the course of a year would use a shared car for 10 weekend trips and 20 trips during weekdays. ${ }^{21} \mathrm{It}$ is assumed an average travel distance of $400 \mathrm{~km}$ per trip for the weekend hire, and an average travel distance of $30 \mathrm{~km}$ per trip, with a hire period of 5 hours, for the weekday hires. With a Peugeot 308 combi from the Norwegian car-sharing organization Bilkollektivet, this would cost NOK 22,500 per year. If the alternative would be to own a small-sized used car worth NOK 150,000, the average annual cost for the same distance traveled would be approximately NOK 41,000. The driver in this example would save NOK 18,500 annually by using a shared car.

Almost all costs of car-sharing are incurred on a per-trip basis, while a large share of the costs of personal car ownership is fixed (e.g. annual fees, insurance, depreciation). Therefore, someone driving less than what is assumed in the example above would save more money, all else being equal. Likewise, someone driving more would save less or not save at all.

To get an idea of the amount of $\mathrm{CO}_{2} \mathrm{e}$-emissions that would result from the indirect rebound effect, one could as a rough approximation look at the amount of $\mathrm{CO}_{2} \mathrm{e}$ emissions that on average result from each monetary unit (e.g. NOK) spent on goods and services. Steen-Olsen et al. (2016) estimates that the carbon footprint embodied in each NOK of final consumption of goods and services on average is $44 \mathrm{~g} \mathrm{CO}_{2} \mathrm{e} / \mathrm{NOK} .^{22}$ The differences between commodities are large. For example, every NOK spent on transport leads to emissions of $95 \mathrm{~g} \mathrm{CO}_{2} \mathrm{e}$, compared to only $29 \mathrm{~g} \mathrm{CO}_{2} \mathrm{e}$ for every NOK spent on housing.

\footnotetext{
${ }^{21}$ This is an example from www.smartepenger.no, see http://www.smartepenger.no/bilokonomi/2005-bilkollektiv for the full example.

22 The researchers used data from the Norwegian consumer expenditure survey combined with a global multiregional input-output database to assess the carbon footprint of Norwegian household consumption in 2012, as well as its annual development since 1999 .
} 
If the driver from the example above spends all the NOK 18,500 he/she saves on other goods and services, assuming average emissions per NOK of $44 \mathrm{~g} \mathrm{CO} 2 \mathrm{e}$, this would translate into annual emissions of $814 \mathrm{~kg} \mathrm{CO} 2 \mathrm{e}$.

As a comparison to the example above, Concito (2015) estimates that the annual indirect rebound effect could be almost 3 tons $\mathrm{CO}_{2} \mathrm{e}$ per year. This is based on the assumptions that every DKK saved will lead to emissions of 78.6 grams $\mathrm{CO}_{2} \mathrm{e}_{1}{ }^{23}$ and annual savings of $D_{K K} 3,000$ per month (DKK 36,000 per year). ${ }^{24}$

\subsubsection{Overall environmental impacts of car-sharing}

The above sections have shown that car-sharing can change consumer behavior, which in turn will lead to environmental impacts. The numerical examples have focused on the potential impacts on $\mathrm{CO}_{2} \mathrm{e}$-emissions, but changes to the production of cars and volume of motor transport will also affect levels of local pollution, acidification and other environmental impacts.

The above sections have shown that car-sharing - overall - reduces the number of cars on the roads and the distance traveled by car. Based on studies from Europe and USA, each shared car could on average replace somewhere between 4 and 13 personal cars. Accounting for potential increases in new-car sales to car-sharing fleets, from more heavy utilization of shared cars, $\mathrm{CO}_{2} \mathrm{e}$ emissions could be reduced by roughly 40 to $140 \mathrm{~kg}$ per member household. Furthermore, results from studies of car-sharing's impact on the number of vehicle kilometers traveled shows a potential reduction ranging between 6 and $45 \%$, with annual emission reductions of between $90 \mathrm{~kg}$ and 840 $\mathrm{kg}$ per member household. These results are summarized in Table 3. The total $\mathrm{CO}_{2} \mathrm{e}$ emission reductions from lower vehicle ownership and fewer kilometers being traveled could range between $130 \mathrm{~kg}$ and $980 \mathrm{~kg}$ per member household per year. Nordic emission reductions are likely somewhat closer to the lower part of the interval than to the higher part.

To provide a point of comparison for the size of this reduction, a one-way trip by airplane from Stockholm to Gothenburg could generate approximately $140 \mathrm{~kg} \mathrm{CO}{ }_{2} \mathrm{e}$ emissions, and a return trip by airplane from Stockholm to London could generate around $990 \mathrm{~kg} \mathrm{CO}{ }_{2} \mathrm{e}$-emissions. ${ }^{25}$

\footnotetext{
${ }^{23}$ Concito (2015) arrives at this estimate by using the marginal usage (that is, how much a consumer spends on consumption of each DKK saved) as an estimate for how much Danes use of each DKK, and assuming that this amount is spent on products with average emissions.

${ }^{24}$ According to the Danish car-sharing provider Letsgo, a member can save between DKK 3,000 and 4,000 per month by being a car-sharing member instead of purchasing a private car (Letsgo Interview 2014, in Concito, 2015).

25 Based on estimate by Chester and Horvath (2009) of life-cycle emissions from a midsize airplane ( $346 \mathrm{~g} \mathrm{CO}_{2} \mathrm{e} / \mathrm{km}$ )

Distance Gothenburg - Stockholm: 398 km. Distance Stockholm - London (return): 2,868 km.
} 
Source: Vista Analyse.

It should be noted that many of the estimates may not be representative in a Nordic context as there are differences in driving patterns and the availability of alternative transport modes between USA and the Nordic countries. Some of the surveys were undertaken several years ago, and the conditions for car-sharing could have changed since then.

A reduced volume of motor transport could also reduce the demand for parking infrastructure. In addition, greater fuel efficiency and the use of electric and hybrid cars in car-sharing fleets could further reduce emissions. However, a switch towards public transport will in turn generate emissions. There is limited evidence in the literature on the environmental impacts of higher fuel efficiency in shared cars, changes in the use of alternative travel modes (i.e. emissions generated from public transportation) or demand for parking infrastructure.

The indirect rebound effect could partly, fully or more than offset the reductions from lower vehicle holdings and reduced car use. In the examples above, the indirect rebound effect is estimated to $814 \mathrm{~kg}$ and 3 tonnes $\mathrm{CO}_{2} \mathrm{e}$-emissions. The size of the effect will depend on the amount of economic savings from car-sharing, how much of the savings car-sharers would spend, and the type of goods and services the money is spent on.

\subsection{Housing/accommodation}

Chapter 3 provides an overview of sharing initiatives in the housing/accommodation market in the Nordic countries. This section will focus on the potential impacts of Airbnb, which is the most prominent sharing initiative within housing/accommodation (see chapter 3 ). The types of changes in consumer behavior described here may also be relevant to other, similar sharing initiatives.

Property rentals through Airbnb may induce both positive and negative environmental impacts. On the one hand, Airbnb properties may be "greener" and generate lower $\mathrm{CO}_{2} \mathrm{e}$-emissions than hotels. Also, the growth of Airbnb could lead to lower demand for hotels and a reduced hotel construction rate. On the other hand, with Airbnb generally being more affordable than hotel rooms, some people may travel more often than they would in the absence of Airbnb, potentially generating increased 
$\mathrm{CO}_{2} \mathrm{e}$-emissions from air travel and/or other transportation modes. These potential impacts are discussed in more detail below.

\subsubsection{Airbnb vs hotels - comparison of energy use and associated emissions}

Airbnb argues that stays at Airbnb properties generate less energy, water, and waste than hotel-stays. For simplicity, this section will only consider the potential difference in energy use and associated $\mathrm{CO}_{2} \mathrm{e}$-emissions.

The energy use of buildings varies with a range of factors, such as location, size, weather conditions and architectural design. In general, one might expect the operational energy use of Airbnb properties to be lower compared to hotels because the latter often have more energy intense facilities, such as bars, restaurants and swimming pools, as well as 24 -hour operation.

There is almost no existing literature on the potential environmental impacts of home-sharing. One reason for this is that sharing platforms have been restrictive and selective in granting researchers access to their user data, for privacy and competition concerns, releasing their own research results instead (Frenken \& Schor, 2017). Airbnb commissioned the Cleantech Group in 2014 to analyze the environmental impacts of home-sharing in North America and the European Union compared to hotel stays. ${ }^{26}$ The findings of the study are based on an analysis of public sources, proprietary Airbnb data and survey responses from over 8,000 Airbnb hosts and guests. ${ }^{27}$ There is limited information available about the method and data used in the analysis as Airbnb has only released a summary of the report.

The study concludes that per guest-night, Airbnb guests use an estimated $78-84 \%$ (150-330 kBtu) less energy than hotel guests and that the $\mathrm{CO}_{2}$-emissions associated with energy use for Airbnb stays are at least an estimated $88 \%\left(20 \mathrm{~kg} \mathrm{CO}_{2}\right)$ lower than for hotel stays. Cleantech considers the impacts from activities that occur at Airbnb properties and hotels. Other, indirect impacts from for example extraction and production of materials, transportation of fuels and electricity generation, are not included in the analysis. Cleantech also finds that Airbnb guests use less water and generate less waste compared to hotel guests.

According to Pérez-Lombard et al. (2008), the average energy intensity of hotels in USA is about 2.1 times higher compared to dwellings. Under the assumption that energy use at Airbnb properties and dwellings is the same, this suggests that energy use could be around $50 \%$ lower at Airbnb properties compared to hotels.

One might expect that energy use by high-end hotels is higher compared to lowerend accommodation (e.g. pensions and motels) because the former often offer more energy-intense facilities and services. If people who choose to stay at Airbnb properties otherwise would have chosen more low-budget accommodation such as pensions and motels with a lower associated energy use, the energy saved from Airbnb-stays would

\footnotetext{
${ }^{26}$ See Cleantech (2014).

${ }^{27} 4,092$ responses from Airbnb hosts. 4,448 responses from Airbnb guests. $39 \%$ of the responses came from EU-countries and $37 \%$ from North America.
} 
be lower. Zervas et al. (2014) analyze the impact of Airbnb on hotel stays in Texas, and finds that the revenue of low-budget accommodation is most affected by Airbnb, while high-end hotels and hotels that cater for business customers are mostly unaffected. ${ }^{28}$

Certain hotel chains are also working actively to reduce energy consumption and become more environmentally friendly. For example, Nordic Choice hotels, which is the largest hotel chain in Scandinavia, is ISO 14001 certified (an international environmental standard), and has implemented measures to reduce its environmental impact. From 2007 to 2011 , the chain reduced its electricity consumption by $7 \% .{ }^{29}$ If hotel chains are reducing their energy consumption and shifting towards renewable energy sources at a faster rate than Airbnb hosts, the gap in energy use and $\mathrm{CO}_{2} \mathrm{e}$ emissions between hotels and Airbnb will narrow.

If travelers decide to stay in an Airbnb apartment instead of in a hotel, the environmental impacts would be determined by the difference between the Airbnb property and the hotel. If, on the other hand, travelers use Airbnb in addition to hotel stays because of more frequent travelling, the environmental benefits would not materialize. Instead, there would be increased emissions from the transport modes used to get to the destination. This issue is discussed in section 4.2.2. Any positive impact on $\mathrm{CO}_{2} \mathrm{e}$-emissions associated with lower energy use at Airbnb properties compared to hotels will therefore only be relevant in instances where Airbnb accommodation substitutes hotel accommodation.

Zervas et al. (2014) find that a $1 \%$ increase in Airbnb listings in Texas result in a $0.05 \%$ decrease in quarterly revenues for the hotels in the same area, with lower-end hotels incurring most of the financial impact. These results suggest that Airbnb, at least to some degree, is a substitute to the hotel industry.

There are few points of comparison for this study as there has been little academic research on the topic. ${ }^{30}$ Airbnb has however commissioned a set of short stories, which argue that the Airbnb business is complementary to the hotel industry because most of Airbnb's properties are located outside central hotel districts (Zervas et al., 2014)..$^{31}$

Underutilization of resources is a key concept in the sharing economy. As with the higher utilization of cars through car-sharing, Airbnb or other home-sharing initiatives utilize idle housing capacity (for example a spare room). If however Airbnb encourages people to buy a second property to rent out, this does not constitute use of idle capacity (Frenken \& Schor, 2017)

Assuming that Airbnb utilizes idle capacity, and that it leads to some substitution away from traditional hotel accommodation, the growth of Airbnb could reduce the

\footnotetext{
${ }^{28}$ Zervas et al. (2014) used data collected from Airbnb.com on over 22,000 stays in the state of Texas over the five year period from 2008 to 2013, and quarterly hotel revenue tax data from over 4,000 hotels in Texas from 2003 to 2013. 29 See the Nordic Choice hotels website; https://www.nordicchoicehotels.com/social-responsibility-in-nordic-choicehotels/our-environmental-commitment/energy/ (Accessed 8 May 2017).

${ }^{30} \mathrm{~A}$ literature search did not return any results for articles from the Nordic countries. A few Master theses have however covered the topic, for example: 1. Ytreberg, Nora Svarstad. "Competitive effects of Airbnb on the Norwegian hotel market." (2016).2. Neeser, D. (2015). Does Airbnb Hurt Hotel Business: Evidence from the Nordic Countries. Master's thesis, Universidad Carlos III de Madrid.

${ }^{31}$ See for example Airbnb (2013), where it is stated that $70 \%$ of Airbnb properties in Paris are located outside the central hotel corridor.
} 
demand for construction of new hotels. Emissions from the construction of new hotels vary significantly with the types of materials used, the size of the hotel etc. Environmental impacts from construction of buildings include $\mathrm{CO}_{2} \mathrm{e}$-emissions, local air pollution and waste from leftover materials.

Energy use from the operation of hotels holds by far the largest share of a building's total life-cycle energy consumption in the form of heating, ventilation, and air conditioning (Filimonau et al., 2011). Researchers have estimated embodied energy, which includes construction, maintenance, refurbishment, development, and demolition of buildings, as a share of total energy use over the life-cycle of a hotel building. According to Filimonau et al. (2011), most researchers estimate the share of embodied energy to be $10-15 \%$, sometimes up to $20 \%$, of the total energy use in most of the conventional and commercial buildings with a life-cycle of 50 to 100 years. Filimonau et al. (2011) assumes embodied energy accounts for $15 \%$ of the total energy use in their Life-cycle Energy Analysis (LCEA) of two tourism accommodation facilities in Poole, Dorset (UK), acknowledging that the estimate lacks precision as it is based on a wide-ranging literature sample.

While there is limited (and potentially skewed) evidence in the literature, Airbnb guests could have a lower energy use and associated $\mathrm{CO}_{2} \mathrm{e}$-emissions than hotel guests. Cleantech (2014) estimates a reduction in $\mathrm{CO}_{2}$-emissions associated with energy use of at least $88 \%\left(20 \mathrm{~kg} \mathrm{CO}\right.$ ) compared to hotel stays. $\mathrm{CO}_{2}$ emissions from energy use in Nordic countries is likely to be lower compared to other European countries because of the high degree of renewable energy in the energy mix.

Nordic Choice hotels reported emissions of $3.71 \mathrm{~kg} \mathrm{CO}_{2} \mathrm{e}$ in 2013 per guest night at their hotels (Nordic Choice hotels, 2016). ${ }^{32}$ For Scandic hotels the emissions per guest night were $2.42 \mathrm{~kg}$ for the first half of the same year (Scandic, 2013). ${ }^{33}$ Note that these emissions are of a completely different order than the emissions in Cleantech (2014), where $\mathrm{CO}_{2}$-emissions associated with energy use are $20 \mathrm{~kg}$ lower in Airbnb properties compared to hotels. If nevertheless it is assumed that emissions are $88 \%$ lower in an Airbnb property, there could be a reduction of approximately $2-3 \mathrm{~kg} \mathrm{CO}_{2} \mathrm{e}$-emissions per guest night. If additionally, the growth of Airbnb reduces the rate of construction of new hotels, the reduction in emissions per guest night could be further increased by $15 \% .{ }^{34}$ This is a rough approximation intended only to provide an indication of the size and direction of the impact of Airbnb on emissions.

\subsubsection{Impact on travel patterns}

Airbnb rooms are often given at a cheaper rate compared to hotel rooms because there's a lower transactional overhead than renting from a traditional provider (Zervas

\footnotetext{
${ }^{2}$ The estimate includes Scope 1, 2 and 3 from the Greenhouse Gas Protocol, i.e. direct emissions, indirect emissions from the generation of purchased electricity, and other indirect emissions from for example transportation of fuels.

33 Emissions generated between January and August 2013. Fossil carbon dioxide emissions. Scandic has not disclosed information about whether both direct and indirect emissions are included in the number.

34 Based on the estimate of embodied energy as a share of total energy consumption by Filimonau et al. (2011) of $15 \%$ and assuming a 1 to 1 relationship between increase in energy use and increase in emissions.
} 
et al., 2014). One can imagine that Airbnb, through lower prices and a different offer, leads to more travel and subsequently more demand for accommodation. This could in part, fully or more than offset the positive impacts described in the section above.

As discussed in chapter 2, the demand for a particular good or service depends on a variety of factors, including the level of household income, the price and quality of the product in question and the price of close substitutes. If a consumer saves money by staying at an Airbnb property, this could increase the demand for Airbnb accommodation because the consumer's disposable income increases (income effect), and Airbnb is relatively cheaper than other goods and services, such as hotel accommodation (substitution effect). The consumer may also decide to spend the money saved on accommodation on other goods and services, which in turn will generate $\mathrm{CO}_{2} \mathrm{e}$-emissions (see description of the indirect rebound effect in section 4.1.2).

Because of a lower accommodation price, people may choose to go on trips that they otherwise would not have taken or to stay longer at a destination. Whether Airbnb induces increased travel depends on the sensitivity of consumers' demand to changes in price and income. The demand for air travel is typically highly sensitive to changes in income and price. That is, the demand for air travel increases by more than the amount income is increased or prices reduced. Aamaas and Peters (2017) have estimated an income elasticity of demand for air travel of 1.69 .35 That is, as income increases by $1 \%$, the demand for air travel increases by $1.69 \%$. This would indicate that a higher disposable income from lower accommodation prices is more likely to be spent on air travel than on other, less elastic goods and services.

Voytenko et al. (2015) report the results of the first stage of an ongoing 3-year project on Urban Reconomy ("sharing for circular resource efficiency") funded by the Swedish Research Council FORMAS..$^{36}$ The results showed that accommodation sharing platforms did not lead to a significant increase in greenhouse gas emissions from air travel compared to incumbent hotel industry, because they were used as a substitution rather than an addition to hotels. However, the researchers found that one third of respondents stayed longer at the destination when they booked accommodation through the sharing platform compared to a stay in a hotel. This could create extra (local) pressure on the environment.

As an illustration of the different impacts on emissions from Airbnb, imagine someone who - because of Airbnb - decided to travel on a return trip by airplane from Oslo to London. The total return distance is $2,300 \mathrm{~km}$. Based on Chester and Horvath's (2009) estimate of $\mathrm{CO}_{2} \mathrm{e}$-emissions per passenger kilometer travelled for a midsize plane, ${ }^{37}$ this trip would generate around $800 \mathrm{~kg} \mathrm{CO} 2$ e. Under the assumption that one

\footnotetext{
35 Estimated mainly based on data from the Norwegian national survey in 2009, whereby around 29,000 persons were interviewed over telephone.

${ }^{36}$ The researchers collected data via a quantitative online survey with the users (i.e. hosts and guests) of five accommodation sharing platforms (Airbnb, Home Exchange, Warm Showers, Couchsurfing and Be Welcome), complemented by 10 in-depth qualitative interviews with eight accommodation sharing platforms ( 9 flats, Airbnb, Behomm, Be Welcome, Guest to Guest, Home Exchange, Trustroots and Warm Showers).

${ }^{37} 346$ grams $\mathrm{CO}_{2}$ e per passenger kilometer traveled. The estimate includes life cycle impacts (emissions from operation, maintenance and manufacturing, infrastructure construction and operation, and energy production).
} 
Airbnb guest night generates $2-3 \mathrm{~kg}$ less $\mathrm{CO}_{2} \mathrm{e}$ than a hotel guest night, Airbnb accommodation would have to substitute around $270-400$ guest nights at hotels to offset these emissions.

In the study commissioned by Airbnb, Cleantech (2014) found that Airbnb induced increased travel in the $\mathrm{EU}$ in 2013, but that the emissions generated from the additional travel was significantly lower $\left(7,500\right.$ metric tons $\left.\mathrm{CO}_{2}\right)$ than the estimated total avoided emissions associated with staying at an Airbnb property instead of a hotel (at least 370,000 metric tons $\mathrm{CO}_{2}$ ). The assumptions and methodology applied for the estimation are not publicly available.

\subsection{Smaller capital goods}

Chapter 3 lists several Nordic sharing economy initiatives that match people who want to rent various small capital objects, such as tools, clothes, furniture etc., with people who want to rent out these kinds of objects. The sharing of small capital objects may lead to positive environmental benefits if it suppresses sales and production of new objects. At the same time, it may under certain circumstances induce increased driving. Sharing initiatives allow the sharing of a range of different objects. This section will analyse the potential impacts from the sharing of tools and clothes based on a couple of examples given by the Danish green think tank Concito in a report about the climate potential of the sharing economy (see Concito, 2015).

\subsubsection{Tools}

Privately owned tools are mostly stored away and only used occasionally. For example, a power drill is only used around 18 minutes over its entire life span (Concito, 2015). The production of a tool generates around $7 \mathrm{~kg} \mathrm{CO} \mathrm{CO}_{2} \mathrm{e}$ per $\mathrm{kg}$ of material..$^{88}$ The English organization WRAP has estimated that the life-cycle emissions from a power drill amount to around $28 \mathrm{~kg} \mathrm{CO}$ e (WRAP 2010, cited in Concito, 2015). Only $2 \%$ of the emissions are generated from the use of the drill.

Concito (2015) provides a hypothetical example of the potential benefits of the sharing of power drills through the Danish online service Lejdet. Lejdet facilitates the sharing of all kinds of items between people, with tools making up the largest share of goods exchanged on the site. In 2014 power drills were shared 30 times via Lejdet (Concito, 2015). Concito (2015) makes the following assumptions:

- 5 electric drills covered 30 rentals, i.e. each of the 5 drills was rented 6 times.

- The sharing suppressed the production of 25 electric drills.

- Production of one power drill generates $28 \mathrm{~kg} \mathrm{CO} 2 \mathrm{e}$-emissions.

${ }^{38}$ Estimated by Concito using SimaPro, which is a life cycle analysis software. 
Based on the assumptions above, the 30 rentals would reduce emissions by $700 \mathrm{~kg}$ (see Table 4).

Table 4: Example - Reduction of $\mathrm{CO}_{2} \mathrm{e}-\mathrm{emissions}$ from sharing of electric power drills

Emissions from the production of 5 power drills Reduced emissions from sharing 5 power drills between 30 people

$140 \mathrm{~kg} \mathrm{CO}_{2} \mathrm{e}$

$700 \mathrm{~kg} \mathrm{CO} 2 \mathrm{e}$

Source: Concito (2015).

It is assumed in the example above that one rental of a power drill will suppress the sale of one drill. Whether this is a realistic assumption depends on what people would have done in the absence of the sharing service. Typically, people will only rent something if they expect this to be cheaper than buying it new. That is, the hire price times the number of expected rentals should be lower than the purchase price. Other reasons for renting instead of buying could be the convenience of not having to store or maintain the object.

The alternative to using a shared tool may not always be to purchase a new one. In the absence of online sharing of tools, people might borrow or rent the tools from somewhere else instead. For example, if someone needs an expensive and specialized machine they only expect to use once, it is likely that they would rent the machine instead of buying a new one (Concito, 2015).

If the sharing services make tools cheaper and more accessible, this could potentially wear out the tools faster. This will depend on how much more the tool is being utilized. If a tool is only used a few more times during its lifetime from being shared, it is unlikely that they would have to be replaced faster from the additional use, considering that most tools are heavily underutilized. In the case that sharing of tools facilitates the use of tools that otherwise would not have been used, there would be an increase in electricity use (for power tools) or fuels (e.g. lawn mowers) and associated environmental impacts.

The availability of sharing services may also induce increased traveling as people pick up the rented tools. Whether this generates environmental impacts depends on the travel mode and the distance traveled. It is likely that people would only be willing to take short trips to pick up tools - for example within their neighborhood or suburb.

Imagine that someone instead of buying a new power drill drives a return trip of 5 kilometers to hire the drill. If the person otherwise would have driven a similar distance to the shop to purchase the drill, there is no difference in emissions. Now imagine the person needs the power drill 9 more times over the years. Driving an average of 5 kilometers each time, with emissions of $173 \mathrm{~g} / \mathrm{km}, 39$ this would generate approximately $8 \mathrm{~kg} \mathrm{CO}{ }_{2} \mathrm{e}$. In this instance, the additional emissions from induced driving would be lower than the $28 \mathrm{~kg}$ emissions from the production of a power drill.

39 Average $\mathrm{CO}_{2} \mathrm{e}$-emissions from a petrol car in Norway in 2015. Source: SSB (2015). 


\subsubsection{Clothes}

Concito (2015) presents an example of the potential emission reductions from the clothes-sharing business Resecond, which facilitates sharing of dresses in Copenhagen and Århus. Customers can bring a dress they are no longer using, and in return pick another dress from the stock. Resecond charges a monthly fee for the service.

Concito (2015) makes the following assumptions:

- A shared dress could be used up to 25 times.

- A owned dress is normally only used 6 times before it is put at the back of the cupboard.

- $1 \mathrm{~kg}$ of clothing generates $24 \mathrm{~kg} \mathrm{CO} \mathrm{CO}_{2} \mathrm{e}$-emissions over its lifetime..$^{\circ}$

- One dress weighs approximately $1.5 \mathrm{~kg}\left(36 \mathrm{~kg} \mathrm{CO}_{2} \mathrm{e}\right)$

- Every time a dress is swapped, it is used one time.

Based on these assumptions, Concito (2015) calculates the potential emission reductions from the recycling of dresses facilitated by Resecond. The results are presented in Table 5.

Table 5: Example-Reduction of COze-emissions from sharing of dresses

\begin{tabular}{lccr} 
& $\begin{array}{l}\text { Dress is recycled in } \\
\text { Resecond 10 times }\end{array}$ & $\begin{array}{l}\text { Dress is recycled in } \\
\text { Resecond 15 times }\end{array}$ & $\begin{array}{r}\text { Dress is recycled in } \\
\text { Resecond 25 times }\end{array}$ \\
$\begin{array}{l}\text { Saved } \mathrm{CO}_{2} \mathrm{e} \text { in kg from } \\
\text { increased use of dresses }\end{array}$ & $144 \mathrm{~kg}^{41}$ & $324 \mathrm{~kg}^{42}$ & $684 \mathrm{~kg}^{43}$ \\
\hline
\end{tabular}

Source: Concito (2015).

As with the example given above for tools, it is important to consider what a person would have been doing in the absence of Resecond. For example, someone might have purchased a dress second-hand instead of buying a new one. In this case, sharing through Resecond would not result in any additional emission reductions.

Sharing could also induce increased travelling, if people travel more to pick up shared clothes compared to the travelling they would have done to buy new clothes. If one dress generates $36 \mathrm{~kg}$ of $\mathrm{CO}_{2}$ e emissions reductions, a person would have to travel around $210 \mathrm{~km}$ by car to offset the emissions reductions. ${ }^{44}$

There exists a range of different business models to facilitate sharing of clothes. Resecond is just one of these. Vigga is another business in Denmark where a package of baby clothes (15-20 pieces) is circulated eight times between members

\footnotetext{
$4^{\circ}$ Estimated by Concito using Sima Pro.

${ }^{41}$ This means suppression of the purchase of 4 dresses, as one dress alternatively would have been used six times. As every dress generates $36 \mathrm{~kg} \mathrm{CO}{ }_{2} \mathrm{e}$, this equals a reduction of $144 \mathrm{~kg}$.

$4^{2}$ Suppression of production of nine dresses.

43 Suppression of production of nineteen dresses.

${ }_{44}$ Assuming average $\mathrm{CO}_{2} \mathrm{e}$-emissions of $173 \mathrm{~g} / \mathrm{km}$. Based on average emissions from a petrol car in Norway in 2015. Source: SSB (2015).
} 
during the first two years of the baby's life. While different business models could have different environmental impacts, the principle of better utilization of clothes is the same for all of them.

As mentioned in the examples of sharing in the transportation and accommodation/housing sectors, lower prices may lead to indirect rebound effects whereby saved money is spent on goods and services, which in turn will generate $\mathrm{CO}_{2} \mathrm{e}-$ emissions. This also applies to sharing of small capital goods.

\subsection{Services}

Chapter 3 presents digital platforms that facilitate sharing of services in the Nordic countries. Examples of the types of services that can be requested/offered include running errands, cleaning services, painting, gardening, house maintenance, transportation of smaller goods etc. Services that in the sharing economy can be done remotely but earlier would have to be done on site could yield considerable environmental benefits.

The key determinant of the environmental impacts of shared services is the extent to which it induces increased driving. This will depend of what the alternative to the provision of the service would have been. Imagine a person paying someone to paint his house, who - in the absence of shared services - would have done it himself or perhaps not painted the house at all. The environmental impact in this instance is the emissions generated from the transportation of the painter to and from the house. However, if the house owner would have paid a painting company to undertake the task, who also would have had to travel to and from the house, there would be no additional environmental impacts from the shared service. Besides, if the house owner had painted it himself, he would have to go (drive) to and from a store to buy the paint.

However, if hiring a painter through a shared service is cheaper than hiring one through a professional company, the house owner would save money and potentially spend these money on goods and services that in turn cause environmental impacts this is the "indirect rebound effect".

Emissions can also be generated directly from the provision of the service itself, such as the transportation of smaller goods. Again, the environmental impact depends on whether these goods would have been transported regardless of the existence of shared services.

Another potential impact, like the case of smaller capital goods, is if someone foregoes the purchase of tools or other equipment needed to undertake an activity because they can hire someone to do it for them. 



\section{Overall environmental and policy implications}

In this Chapter we summarize the main findings of our analysis and discuss what policy implications this should eventually lead to.

\subsection{Several sharing initiatives have a potential to contribute to environmental improvements}

Our mapping of sharing economy initiatives in the Nordic countries shows that there are several initiatives in transportation, housing/accommodation, sharing/renting of smaller capital goods and services that could lead to environmental improvements. Most initiatives are related to the transport sector, and it is in this sector where the direct potential for emissions reductions is largest. Analyses show that there is a potential for $\mathrm{CO}_{2} \mathrm{e}$ emissions reductions from reduced driving of private cars and reduced car production. But there are likely similar impacts on NOx, PM and other pollutants causing local air pollution, noise, emissions of hazardous substances etc., especially since most of these initiatives are located in cities where local environmental problems from transport are largest. Also in other sectors like accommodation, small goods and services, there are emission reduction potentials from using existing equipment and goods more instead of producing more equipment that is less used.

We have analyzed the potential for emissions reductions from sharing alternatives that offer services with lower prices and/or better qualities compared to owning and driving one's own car, but there are several other transportation sharing initiatives that could yield similar reductions. Carpooling, where people for instance ride together to and from work, could lead to emissions reductions if people previously drove their own car instead. Car hailing initiatives could yield similar benefits if people drive their own car less and/or don't own a car any more.

The environmental benefits result from changing peoples' behavior away from emissions intensive activities to less intensive ones. Thus, if there are environmental benefits from sharing economy initiatives depend on how people change their behavior. Some would for instance drive more when cars become more available, thus offsetting some of the initial positive benefits. The same will happen if some people instead of traveling with public transport start driving shared cars. It is of course uncertain what the total, environmental impacts of these initiatives would be, but analyses of car sharing initiatives indicate that the impacts on $\mathrm{CO}_{2}$ e emissions resulting from reduced price and/or improved quality/better availability of these services are 
positive. Similar, positive impacts from reduced price and/or better quality/availability are likely also from various sharing initiatives in other sectors.

But we also know that when people save money from reduced prices of some services, they will use all or some of these savings on other goods and services causing environmental harm. We have found that for instance savings from participating in a car sharing arrangement instead of owning one's own car could be considerable, and the use of these savings on other goods and services could partly, fully or more than offset initial environmental improvements. For instance, it is likely that people will travel more by air when they get richer, which will cause large increases of $\mathrm{CO}_{2} \mathrm{e}$ emissions. A particular concern here might be that cheap accommodation through sharing initiatives could spur people to travel more by air.

\subsection{Sharing initiatives' impacts on overall emissions depend on the environmental policy instruments used}

So will these various sharing initiatives lead to environmental improvements? If we first look at $\mathrm{CO}_{2}$ e emissions, it is likely that the initiatives will have only a small or no impact on overall emissions. In the Nordic countries $\mathrm{CO}_{2} \mathrm{e}$ emissions from transportation and some other sectors are taxed through fuel taxes, and in some countries also through purchase taxes on vehicles.

Furthermore, $\mathrm{CO}_{2} \mathrm{e}$ emissions from aviation, electricity, car and building material production and most other production activities are covered by the EU emissions trading scheme ETS, which also comprises Iceland and Norway (together with EU they are the European Economic Area, EEA). Thus, if for instance emissions from aviation increase, emissions from other sectors covered by the trading scheme must be reduced to keep overall emissions within the total cap (this requires that the cap is effective, which it hasn't always been). Also, electric cars are indirectly covered by the emissions trading system because power production is part of the system. $\mathrm{CO}_{2}$ e emissions from increased use of energy in hotels and other buildings are also covered by the EU ETS system, as most emissions from the construction of new buildings.

This shows that when countries have introduced cost efficient climate change policies, where all $\mathrm{CO}_{2}$ and other GHG emissions have the same price either through a tax or emissions trading system, people are faced with a price on emissions, so that this is taken into account when they make their choices on what to spend their money on. People change their demand for goods and services all the time because of changes in prices, quality etc. caused among other things by new, improved goods and services coming on the market. Since almost all human activities cause some $\mathrm{CO}_{2} \mathrm{e}$ emissions through production, consumption and waste handling, it is important that all emissions are priced so that producers and consumers can take this into account when they make their choices. The case with the sharing economy also illustrates that when using taxes, they would have to be adjusted over time as we get richer to avoid overall emissions to increase. In an emission trading system the $\mathrm{CO}_{2}$ price will automatically adjust to increases in emissions through increased demand for emission allowances. 
But not all $\mathrm{CO}_{2} \mathrm{e}$ emissions are covered by taxes or EU ETS. Most of the policy measures cover only $\mathrm{CO}_{2}$, and not other GHG. Goods imported from outside the EEA are often not covered by any emissions regulations, for instance does the EU ETS only cover intra-EEA flights. But this could change in the future, for instance will more international flights be regulated from the mid-2020s through a scheme adopted I by the International Civil Aviation Organization, requiring that increases in emissions must be offset through emissions reductions measures. Also, countries outside the EEA could eventually take actions against other $\mathrm{CO}_{2}$ e emissions.

If we look at impacts on local environmental problems the picture is more nuanced. Road transport is an important contributor to problems related to local air pollution, noise, road congestion and accidents, and these problems mostly occur in (larger) cities. As far as the sharing initiatives lead to less driving in cities they would have positive impacts on these problems. Carpooling and car sharing might make congestion regulations etc. more efficient by offering alternatives to driving alone in private cars. Even if transport isn't reduced substantially, car sharing initiatives might contribute to improved air quality by speeding up the introduction of low and zero emission cars.

In the long run impacts from the sharing economy initiatives might be somewhat different. If we all in some years drive in zero emission, (self-driven) cars, car transport will no longer contribute to $\mathrm{CO}_{2} \mathrm{e}$ emissions and reduced local air quality. The sharing initiatives could contribute to speeding up the introduction of self-driven cars also, and become an element in an integrated, intermodal transport system. TØ। (2016) foresees that in the future personal cars are no longer common, at least in cities, and that fleets of autonomous electric vehicles provide transportation with higher levels of service, faster rides and increased safety at a far lower price than today's individually owned cars. These fleets could include a wide variety of vehicle types, sizes and configurations that meet every kind of consumer needs. There are several research initiatives in the Nordic countries, for instance through the project "Charming cities: Shared Mobility for Innovative and Inclusive Green Cities" by the University of Oslo and several partners, that try and look into how the various car sharing initiative could shape our cities.

\subsection{Sharing initiatives should be encouraged, and all emissions should be priced or regulated}

Sharing economy initiatives could yield considerable benefits to consumers by offering lower prices and/or higher quality on the capital goods and services, particularly in the transport and accommodation sector. They might also improve the overall efficiency of the economy, leading to better/more use of existing cars, dwellings and other goods, and reduced production of new units. Authorities should take the opportunity to go through various regulations to see if there are some (un-necessary) ones that are hampering the introduction of sharing initiatives, and eventually could be removed.

More efficient use of the resources through sharing initiatives could also contribute to environmental benefits, but this is far from certain if emissions are not regulated properly through taxes, emissions trading or similar. Sharing initiatives would lead to 
various changes in how people utilize goods and services, and the overall impacts on emissions are hard to foresee. But if all $\mathrm{CO}_{2} \mathrm{e}$ emissions have a high price, and local environmental challenges are regulated properly, sharing initiatives should contribute to higher consumer benefits and a more efficient economy at least without harming the environment. 


\section{References}

Airbnb action (2016): Airbnb har gjennomført samtlige "Economic Impact"-reports. URL: https://www.airbnbaction.com/category/economic-impact/

Airbnb (2013): New Study: Airbnb community contributes EUR 185 million to Parisian economy.

Aamaas, B. \& Peters, G.P. (2017): The climate impact of Norwegians' travel behavior. Travel behavior and society 6 (2017) 10-18.

Boston Consulting Group (2016): What's ahead for car-sharing? The new mobility and its impact on vehicle sales.

Chen, T.D. \& Kockelman, K.M. (2016): Car-sharing's life-cycle impacts on energy use and greenhouse gas emissions. Transportation Research Part D: Transport and Environment 47, 276-284. https://doi.org/10.1016/j.trd.2016.05.012

Chester, Mikhail and Arpad Horvath (2009): Environmental Assessment of Passenger Transportation Should Include Infrastructure and Supply Chains, Environmental Research Letters 4(2). https://doi.org/10.1088/1748-9326/4/2/024008

Cleantech (2014): Environmental Impacts of Home Sharing. Phase 1 Report, April 30, 2014: Prepared by Cleantech Group for Airbnb.

Concito (2015): Deleøkonomiens klimapotentiale, Rapport 12. Juni 2015

Concito (2010): Forbrugerens klimapåvirkning. Rapport 20. december 2010.

Department for Transport (2004): Making Car Sharing and Car Clubs Work: Final Report. DfT, London, UK.

Einav L., C. Farronato og J. Levin (2016): Peer-to-Peer Markets, The Annual Review of Economics, 8:6-15-35, Reviews in Advance.

Engel-Yan, J. and Passmore, D. (2013): Car-sharing and Car Ownership at the Building Scale: Examining Potential for Flexible Parking Requirements. Journal of the American Planning Association 79(1), pp. 82-91. https://doi.org/10.1080/01944363.2013.790588

FAFO (2016): Nordic labor markets and the sharing economy.

Filimonau, V., Dickinson, J., Robbins, D. \& Huijbregts, M.A.J. (2011): Reviewing the carbon footprint analysis of hotels: Life-cycle energy analysis (Icea) as a holistic method for carbon impact appraisal of tourist accommodation. Journal of Cleaner Production, vol. 19, iss. 17-18, pp. 1917-1930. https://doi.org/10.1016/j.jclepro.2011.07.002

Frenken, K., \& Schor, J. (2017): Putting the sharing economy into perspective. Environmental Innovation and Societal Transitions.

Gansky, L. (2010): The Mesh: Why The Future of Business Is Sharing. Penguin Publishing Group.

Gossling, S, Peeters, P., Ceronc, J-P., Duboisd, G., Pattersone, T. \& Richardson, R.B. (2005): The Eco-Efficiency of Tourism. Ecological Economics, vol. 54, no.15, pp. 417-434.

https://doi.org/10.1016/j.ecolecon.2004.10.006

Goudin P. (2016): The Cost of Non-Europe in the Sharing Economy; EPRS: European Parliamentary Research Service.

Martin, E. \& Shaheen, S. (2016): Impacts of Car2Go on vehicle ownership, modal shift, vehicle miles traveled, and greenhouse gas emissions: An analysis of five North American cities.

Martin, E. \& Shaheen, S. (2011): Greenhouse gas emission impacts of car-sharing in North America. IEEE Transactions on Intelligent Transportation Systems 12(4), 1074-1086. https://doi.org/10.1109/TITS.2011.2158539

Martin, E., Shaheen, S.A., \& Lidicker, J. (2010): Impact of Car-sharing on Household Vehicle Holdings: Results from North American Shared-Use Vehicle Survey. Transportation Research Record 2143, pp. 150-158. https://doi.org/10.3141/2143-19 
Momo (2010): The state of European car-sharing. Final Report 2.4 Work Package 2. June 2010. Nemry, F., Leduc, G. Mongelli, I. \& Uihlen, A. (2008): Environmental Improvement of Passenger Cars (IMPRO-Car), Joint Research Centre, Institute for Prospective Technological Studies, Seville, Spain.

Nijland, H., Meekerk, J. \& Hoen, A. (2015): Impact of car sharing on mobility and $\mathrm{CO}_{2}$ emissions. PBL Netherlands Environmental Assessment Agency, publication number 1842. July 2015.

Nordic Choice Hotels (2016): Annual report. Available from: (Accessed 8 May 2017).

Pérez-Lombard, L., Ortiz, J., \& Pout, C. (2008): A review on buildings energy consumption information. Energy and buildings, 40(3), 394-398.

https://doi.org/10.1016/j.enbuild.2007.03.007

Ryden, C \& Morin, E (2005): Environmental Assessment Report WP 6, moses deliverable D6.2, version 1.1, 18 January 2005.

Sharing Economy (2017): (n.d.) In Wikipedia. Retrieved 28 March 2017, from https://en.wikipedia.org/wiki/Sharing_economy

Scandic (2013): Scandic reduces its environmental impact. Sustainability report - first half of 2013. Press release. Stockholm, 2 September 2013.

Schneiderman E. (2014): Airbnb in the city. This report was prepared by the Office of the Attorney General of the State of New York's Research Department and Internet Bureau.

SSB (2015): Utslipp fra veitrafikken i Norge. Dokumentasjon av beregningsmetoder, data og resultater. Rapport nr. 2015/22, Statistisk Sentralbyrå, Oslo.

Stasko, T.H., Buck, A.B., \& Gao, H.O. (2013): Carsharing in a University Setting: Impacts on Vehicle Ownership, Parking Demand, and Mobility in Ithaca, NY. Transport Policy 30, pp. 262-268.

https://doi.org/10.1016/j.tranpol.2013.09.018

Steen-Olsen, K., Wood, R., \& Hertwich, E. G. (2016): The carbon footprint of Norwegian household consumption 1999-2012. Journal of Industrial Ecology, 20(3), 582-592. https://doi.org/10.1111/jiec.12405

Stephany, A. (2015): The Business of Sharing: Making it in the New Sharing Economy. Palgrave Macmillan UK.

Sundararajan, A. (2016): The Sharing Economy: The End of Employment and the Rise of CrowdBased Capitalism. The MIT Press.

The Economist (2016): Uber; From zero to seventy (billion). Printed version, 3 September 2016.

The Nordic Council of Ministers (2016): Invitation to open tender for a project on Environmental impact and potential of the sharing economy.

TØI (2016) Mobilitet når du trenger det: Bildeling og innovative forretningsmodeller. Presentasjon på TØ।-frokostseminar: Delemobilitet - et svar på fremtidens transportutfordring? Ove Langeland, forskningsleder TØ।.

TØI (2011): Bildeling i hovedstadsområdet. Rapport 1156/2011, Transportøkonomisk Institutt, Oslo.

Vista Analyse. (2016): Delingsøkonomiens betydning for norsk økonomi - i dag og i fremtiden. VArapport 2016-45. Vista Analyse, Oslo.

Voytenko et.al. (2015): Sharing Economy and Sustainability: Zooming in on Accommodation Sector. International Institute for Industrial Environmental Economics (IIIEE) at Lund University.

World economic forum (2009): The Travel \& Tourism Competitiveness Report 2009-Managing in a time of turbulence. Geneva, Switzerland.

Zervas, G., Davide, P. \& Byers, J.W. (2014): The rise of the sharing economy: Estimating the impact of Airbnb on the hotel industry. Journal of Marketing Research. 


\section{Sammendrag}

\section{En digital plattform, underutnyttede ressurser og personer kjennetegner delingsøkonomien}

Konseptet "delingsøkonomi" er relativt nytt, og det finnes ingen omforent definisjon av hva den omfatter eller hvor omfattende de ulike delingsinitiativene er. Etter vår vurdering kan initiativene innenfor delingsøkonomien defineres slik at de må oppfylle de følgende tre kriteriene:

- Transaksjonen må omfatte en tjeneste basert på fysiske varer eller kompetanse. Overføring av eierrettigheter er ikke inkludert.

- En digital platform (app) er en vital del av tjenesten i form av et mellomledd mellom kjøper og selger, og/eller som del av kvaliteten på tjenesten.

- Initiativet er etablert for å utføre tjenesten under det første kulepunktet med hjelp av teknologien under det andre kulepunktet.

Disse kriteriene er pragmatiske, men søker å omfattet hva som er kjernen i delingsøkonomien. Innenfor dette er initiativene som tilbyr transaksjoner mellom personer/forbrukere $\left(\mathrm{C}_{2} \mathrm{C}\right)$ og mellom foretak og personer $\left(\mathrm{B}_{2} \mathrm{C}\right)$ så vel som mellom foretak (B2B). Kriteriene dekker de mest kjente initiativene som Uber, Airbnb og liknende. Flere foretak fra den "gamle" økonomien utvikler også digitale platformer for å møte konkurransen fra delingsøkonomien, f.eks. ved å tilby ulike strømmetjenester. Vi har ikke inkludert disse i vår gjennomgang ettersom vi har ønsket å fokusere på de nye initiativene som tilbyr andre løsninger enn tradisjonelle foretak.

\section{Vår analyse dekker fire områder}

Vår hensikt har vært å gi en oversikt over noen eksisterende initiativ innenfor delingsøkonomien i de nordiske landene, analysere endringene i forbrukeradferd som følge av dette, og vurdere hvilke miljømessige konsekvenser disse endringene kan føre til. Vi har fokusert på følgende fire segmenter av delingsøkonomien:

- Transport: Ulike bildelingsinitiativ med eller uten sjåfør, samkjøring, transport av varer o.l.

- Overnatting: Tilgang til billig overnatting i private hjem. 
- Andre, mindre kapitalgjenstander: Ulike maskiner og verktøy som forbrukerne kan låne/leie i stedet for å kjøpe.

- Tjenester: En stor gruppe ulike aktiviteter knyttet til personlige tjenster.

\section{Transport har det største potensialet for utslippsreduksjoner}

Vår gjennomgang av initiativene innenfor delingsøkonomien i de nordiske landene viser at det er flere initiativ som kan føre til miljøforbedringer. De fleste initiativene er knyttet til transportsektoren, og det er i denne sektoren hvor det direkte potensialet for utslippsreduksjoner er størst. Det er et potensial for $\mathrm{CO}_{2}$-ekvivalente $\left(\mathrm{CO}_{2} \mathrm{e}\right)$ utslippsreduksjoner gjennom redusert bruk av privatbiler og redusert bilproduksjon, og redusert påvirkning på lokal luftkvalitet, støy, kø etc. ettersom de fleste av initiativene er lokalisert I byer hvor lokale problemer knyttet til transport er størst.

Vi har analysert potensialet for utslippsreduksjoner fra delingsalternativer som tilbyr tjeneste med lavere priser og/eller bedre kvalitet sammenliknet med å eie og kjøre sin egen bil, men det er flere andre initiativ innenfor transportsektoren som kan føre til tilsvarende reduksjoner. Samkjøring, hvor folk kjører sammen til og fra arbeid, kan føre til utslippsreduksjoner hvis man tidligere I stedet kjørte egen bil. Initiativ som tilbyr bil med sjåfør kan gi tilsvarende utslippsreduksjoner hvis folk bruker egen bil mindre eller ikke lenger har egen bil.

Internasjonale studier viser at husholdningene i gjennomsnitt ser ut til å redusere bilholdet etter å ha blitt medlemmer av et bilkollektiv, og indikerer at en delt bil kan erstatte ca. 4-13 personlig eide biler. Ved å ta hensyn til mulige økninger i nybilsalget til bildelingsflåter og høyere utnyttelse av delte biler, kan $\mathrm{CO}_{2}$-utslippene bli redusert med i størrelsesorden 40-140 kg per medlemshusholdning per år som følge av redusert produksjon og vedlikehold etc. av biler. Husholdninger som erstatter egen bil med en delt bil kjører gjerne mindre, fordi delte biler er relativt mindre tilgjengelige og kostnadene per kjøretur blir mer synlige sammenliknet med når man eier egen bil, selv om totale bilkostnader kan bli redusert. Men noen husholdninger som slutter seg til bildelingsløsninger kjører mer enn før, ettersom kjøreturer som tidligere ikke ble foretatt eller foretatt via kollektivtransport, sykkel eller gange i stedet foretas med en delt bil. Den gjennomsnittlige nettovirkningen er en nedgang i antall kjørte kilometer tilsvarende en utslippsreduksjon på mellom $90 \mathrm{~kg}$ og $840 \mathrm{~kg} \mathrm{CO}$ e per husholdning per år i følge de studiene vi har gjennomgått.

Den totale utslippsreduksjonen kan bli mellom i størrelsesorden $130 \mathrm{~kg}$ og $1.000 \mathrm{~kg}$ $\mathrm{CO}_{2}$ e per husholdning per år i følge disse estimatene. Disse tallene er selvfølgelig svært usikre, og siden de høyeste anslagene er fra USA er det ikke sikkert de representerer nordiske forhold når det kommer til utkjørte distanser og utslipp per distanse. Nordiske utslippsreduksjoner vil derfor sannsynligvis ligge nærmere den laveste delen av intervallet enn den høyeste.

Redusert bilbruk kan også redusere etterspørselen etter parkeringsplasser. I tillegg kan bedre drivstoffeffektivitet pga. nyere biler og kanskje også større innslag av el- og hybridbiler i bildelingsflåtene sammenliknet med privatbiler ytterligere bidra til å 
redusere utslippene. Men bruken av kollektivtransport vil sannsynligvis også øke noe pga. redusert bilhold, noe som kan øke utslippene litt.

Når folk sparer penger pga. reduserte priser på noen tjenester vil de bruke hele eller noe av besparelsen på andre varer og tjenester som gir miljøulemper. Vi har funnet at besparelsene ved å være medlem i f.eks. et bilkollektiv i stedet for å eie egen bil kan være betydelige, og at bruken av disse besparelsene kan delvis, helt eller mer enn oppveie de opprinnelige miljøforbedringene. Eksempler fra Danmark og Norge indikerer at de indirekte (såkalte rebound) effektene kan være så høye som henholdsvis 3 tonn og 814 kg CO 2 -utslipp per bildelingsmedlem per år når vi legger til grunn anslag for utslipp fra "gjennomsnittlig forbruk". Størrelsen på denne virkningen vil avhenge av størrelsen på den økonomiske besparelsen fra å delta i bildeling, og hvor mye av og på hvilke varer og tjenester deltakerne vil bruke pengene på.

\section{Overnatting har også et potensial for utslippsreduksjoner}

Leie av privat overnatting gjennom Airbnb og liknende initiativ kan gi lavere $\mathrm{CO}_{2} \mathrm{e}-$ utslipp fordi disse eiendommene kan generere lavere utslipp enn hoteller. Dette skyldes at hoteller ofte har mer energi-intensive fasiliteter som barer, restauranter, svømmebasseng og 24-timers service. Det er også mulig at Airbnb-gjester genererer mindre vannforbruk og mindre mengder avfall enn hotellgjester. Men Airbnb-gjester konkurrerer hovedsaklig med overnatting på herberger og moteller, som generelt har lavere utslipp og andre miljøvirkninger enn hoteller i den andre enden av skalaen. Noen nordiske hotellkjeder i den øvre enden av skalaen arbeider aktivt med å redusere energiforbruket og bli mer miljøvennlige, noe som betyr at forskjellene mellom de ulike overnattingsalternativene reduseres. En studie bestilt av Airbnb anslår at brukerne deres reduserer energibruken med minst 88 prosent sammenliknet med å bo på hotell. Ved å benytte dette anslaget på utslippsdata fra Nordic Choice- og Scandic-hotellene kan det være en reduksjon i utslippene på 2-3 $\mathrm{kg} \mathrm{CO}_{2}$ e per gjestenatt ved å bruke Airbnb og liknende initiativ i stedet for å benytte nordiske hoteller.

Leie av privat overnatting kan redusere etterspørselen etter nye hoteller på lang sikt. Dette kan gi reduserte $\mathrm{CO}_{2} \mathrm{e}$-utslipp og lokal forurensning fra byggeprosessen og produksjonen av bygningsmaterialer, samt mindre generering av avfall. Energibruken fra driften utgjør imidlertid i størrelsesorden 85 - 90 prosent av totale utslipp gjennom hotellenes livssyklus.

Lavere leiepriser kan øke etterspørselen etter privat overnatting, enten gjennom lengre opphold eller flere reiser. Dette avhenger av følsomheten av forbrukernes etterspørsel som følge av endringer i pris og inntekt. Etterspørselen etter flyreiser er typisk svært følsom for endringer i inntekt og pris, noe som innebærer at etterspørselen øker mer enn økningen i inntekt eller reduksjonen i pris. Dette indikerer at det er mer sannsynlig at en høyere disponibel inntekt som følge av lavere overnattingspriser blir benyttet på flyreiser enn på andre, mindre pris- og inntektselastiske varer og tjenester. Hvis en person som følge av billigere overnatting velger å reise en ekstra tur fra Oslo til London og tilbake, kan dette generere en utslippsøkning på $800 \mathrm{~kg} \mathrm{CO}{ }_{2}$. Privat 
overnatting må da substituere i størrelsesorden 270-400 gjestedøgn på hoteller for å motvirke disse utslippene i henhold til tallene ovenfor.

\section{Leie av mindre kapitalvarer kan også gi utslippsreduksjoner}

Det er flere nordiske delingsøkonomi-initiativ som matcher folk som ønsker å leie forskjellige mindre kapitalgjenstander, slik som verktøy, klær etc. Privateid verktøy brukes sjelden. En elektrisk drill brukes f.eks. bare rundt 18 minutter over hele sin levetid i følge en studie. Utslippene fra en eldrill utgjør ca. $28 \mathrm{~kg} \mathrm{CO}{ }_{2}$ e gjennom hele livssyklusen, og bare 2 prosent av utslippene genereres fra bruken av drillen.

Et eksempel fra danske Lejdet, som formidler deling av alle slags ting, viser at i 2014 ble eldriller delt 30 ganger. Hvis 5 eldriller dekket 30 utleier, dvs. hver av de 5 drillene ble leid 6 ganger, vil delingen unngå at 25 eldriller blir produsert, noe som reduserer utslippene med $700 \mathrm{~kg} \mathrm{CO}{ }_{2}$. Men delingstilbudet kan også føre til økt transport for å hente og levere tilbake det leide verktøyet. Hvis noen gjennomfører en tur/returreise på $5 \mathrm{~km}$ for å hente en drill i stedet for å kjøre en tilsvarende distanse for å kjøpe en drill, vil det ikke være noen forskjell $i$ utslippene. Hvis vi antar at personen trenger eldrillen ytterligere 9 ganger over årene, og kjører i gjennomsnitt $5 \mathrm{~km}$ hver gang, så vil dette med utslipp på $173 \mathrm{~g} / \mathrm{km}$ generere utslipp på ca. 8 kg CO${ }_{2}$ e. I dette tilfellet vil de økte utslippene fra økt kjøring være lavere enn de $28 \mathrm{~kg}$ utslipp som spares fra produksjonen av en eldrill.

Men alternativet til å bruke et delt verktøy vil ikke bestandig være å kjøpe et nytt. I fravær av en nettbasert leiemulighet kan folk låne eller leie verktøy fra noen i nærområdet i stedet. Mer bruk av underutnyttet verktøy fordi leie blir rimeligere kan resultere i økt elforbruk (for elbasert verktøy) eller drivstoff (for eksempel for plenklippere) med tilhørende miljøeffekter.

Et annet eksempel er hentet fra klesleieselskapet Resecond, som tilbyr leie av kjoler I København Århus. Kunder kan komme med en kjole som ikke lenger brukes, og $\mathrm{i}$ stedet ta med seg en annen kjole fra utvalget. Hvis en kjole som antas å bli benyttet 6 ganger og så kastes i stedet resirkuleres 10, 15 eller 25 ganger kan en redusere utslippene med henholdsvis 144,324 or $684 \mathrm{~kg} \mathrm{CO}$ e fra reduserte kjøp av nye kjoler. Men hvis man kjøper en brukt kjole i stedet for å kjøpe en ny, vil ikke delingen resultere I noen ytterligere utslippsreduksjoner. Også hvis folk reiser mer for å hente delte klær sammenliknet med reisene de ville ha foretatt for å kjøpe nye klær, vil utslippsreduksjonene være lavere eller til og med øke.

\section{Tjenester ser ut til å ha mindre potensiale for utslippsreduksjoner}

Noen selskap innenfor delingsøkonomien tilbyr formidling av tjenester som transport av mindre gjenstander, å gjøre ærender, renhold, maling, hagearbeid, vedlikehold etc. i de nordiske landene. Miljøvirkningene av disse avhenger i stor grad av om tjenestene kan utføres uten å være til stede hos oppdragsgiver eller om man må være der for gjennomføringen. Førstnevnte tjenester som tidligere måtte gjennomføres på stedet kan gi betydelige miljøforbedringer. 
Tjenestene som krever fysisk tilstedeværelse er typisk manuelle jobber, og selskapene kobler brukerne sammen gjennom digitale plattformer. Mye av dette er jobber som folk tidligere måtte gjøre selv eller få hjelp til fra andre, slik som naboer eller slektninger.

Miljøvirkningene av disse delte tjenestene avhenger av om de fører til økt kjøring. Dette vil avhenge av hva alternativet til tjenesten ville ha vært. Hvis en person i stedet for å betale noen for å male huset sitt ville ha gjort det selv eller kanskje ikke malt huset i det hele tatt, vil miljøvirkningene være utslippene som genereres fra transporten av maleren til og fra huset. Men hvis huseieren hadde malt huset selv, ville han kanskje dratt (kjørt) til en butikk for å kjøpe maling. Hvis huseieren hadde betalt et malerfirma for å gjøre jobben, og som også måtte kjøre til og fra huset, ville det ikke blitt noen miljøvirkninger av delingsinitiativet. Og hvis huseieren sparer penger på å bruke den nye tjenesten, vil han bruke (noe av) besparelsen på varer og tjenester som igjen vil ha miljøvirkninger.

\section{Delingsinitiativenes miljøvirkninger avhenger av virkemiddelbruken i miljøpolitikken}

I de nordiske landene er $\mathrm{CO}_{2}$-utslippene fra transport og en del andre sektorer avgiftsbelagt gjennom drivstoffavgifter, og i noen land også gjennom kjøpsavgifter på kjøretøy. Videre er $\mathrm{CO}_{2}$-utslippene fra luftfart, produksjonen av el, biler og bygningsmaterialer og de fleste andre produksjonssektorer omfattet av EUs kvotehandelssystem ETS, som også omfatter Island og Norge. Dette betyr at dersom for eksempel utslipp fra luftfarten øker, så vil utslippene fra andre sektorer som omfattes av systemet reduseres slik at de samlede utslippene holder seg innenfor utslippstaket for systemet, gitt at taket er effektivt, noe det ikke bestandig har vært.

Når landene har introdusert kostnadseffektive klimapolitiske virkemidler, hvor alle utslipp av $\mathrm{CO}_{2}$ og andre klimagasser har samme pris enten gjennom en avgift eller et kvotesystem, vil folk stå overfor en pris på utslippene som de vil ta i betraktning når de vurderer hva de skal bruke pengene på.

Men ikke alle klimagassutslippene er omfattet av avgifter eller EU ETS. De fleste virkemidlene omfatter bare $\mathrm{CO}_{2}$ og ikke andre klimagasser. Varer importert fra utenfor EØS-området er ofte ikke omfattet av noen virkemidler, f.eks. dekker EU ETS bare flyreiser innenfor EØS-området. Men dette kan endres I framtiden, ettersom land utenfor EØS kan tenkes å innføre virkemidler mot $\mathrm{CO}_{2}$-utslipp.

Veitransport er en viktig bidragsyter til problemer knyttet til lokal luftkvalitet, støy, kø og ulykker, og disse problemene forekommer stort sett i (større) byer. I den grad delingsinitiativene fører til mindre kjøring i byene vil de ha positiv virkning på disse problemene. Samkjøring og deling kan gjøre køregulering etc. mer effektiv gjennom å tilby alternativer til å kjøre alene i egen bil. Selv om trafikken ikke reduseres særlig kan bildelingsinitiativene bidra til forbedret luftkvalitet ved å framskynde overgangen til lav- og nullutslippskjøretøy.

I det lange løp kan virkningene av delingsøkonomiske initiativ bli noe forskjellige fra i dag. Hvis vi alle om noen år kjører rundt i nullutslipps- (selvkjørende) kjøretøy, vil ikke biltransport bidra til $\mathrm{CO}_{2} \mathrm{e}$-utslipp og redusert luftkvalitet. Delingsinitiativene kan 
bli et element $\mathrm{i}$ et integrert, intermodalt transportsystem. En kan se for seg at $\mathrm{i}$ framtiden er privateide biler ikke vanlig, i alle fall ikke i byene, og at flåter av autonome, elektriske kjøretøy tilbyr transport med høyere servicenivå, raskere fremkommelighet og økt sikkerhet til en lavere pris enn dagens privateide biler. Disse flåtene kan inkludere svært ulike typer kjøretøy, størrelser og utforminger som kan møte et hvert behov forbrukerne måtte ha. Men i byene vil det fortsatt kunne være problemer med med kø og eventuelt støy, noe som må håndteres på en eller annen måte.

Det bør legges til rette for delingsinitiativer, og alle utslipp bør prises eller reguleres påannen måte

Initiativer innenfor delingsøkonomien kan gi store gevinster for forbrukerne, og kan også forbedre økonomienes virkemåte og føre til bedre/større utnyttelse av eksisterende kjøretøy, boliger og andre gjenstander samt redusert produksjon av nye enheter. Myndighetene bør benytte sjansen til å gjennomgå ulike reguleringer for å

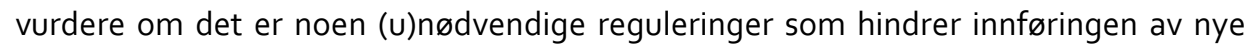
delingsøkonomiske initiativ, og som eventuelt kan fjernes.

Mer effektiv ressursbruk gjennom ulike delingsinitiativ kan også bidra til miljøforbedringer, men dette avhenger av hvordan folk endrer sin adferd og bruker gevinstene fra delingsinitiativene. Men hvis alle klimagassutslippene står overfor en høy pris, og lokale miljøproblemer er hensiktsmessig regulert, bør delingsøkonomien bidra til en mer effektiv økonomi i det minste uten å forverre miljøet. 
Nordic Council of Ministers

Nordens Hus

Ved Stranden 18

DK-1061 Copenhagen K

www.norden.org

ENVIRONMENTAL IMPACTS AND POTENTIAL OF THE SHARING ECONOMY

The various sharing initiatives seen in the Nordic countries over the last years within transportation, housing/accommodation, sharing/renting of smaller capital goods and personal services could yield considerable benefits for consumers due to better quality and/or lower prices of the services. They also have a potential for emissions reductions of $\mathrm{CO}_{2}$ and local pollutants. However, savings from lower prices could lead to increased emissions from increased demand of the services (particularly transport) and increased spending on other goods and services. Depending on how consumers spend their savings, these changes could partly, wholly or more than offset the initial emission reductions. The impacts on overall $\mathrm{CO}_{2}$ emissions depend on whether the emissions are taxed, part of the emissions trading system EU ETS or not regulated at all. 